\title{
Effects of ammonia stress in the Amazon river shrimp Macrobrachium amazonicum (Decapoda, Palaemonidae)
}

\author{
Marcelo R. Pinto ${ }^{a}$, Malson N. Lucena ${ }^{a}$, Rogério Oliveira Faleiros ${ }^{b}$, \\ Eduardo Alves Almeida ${ }^{c}$, John C. McNamara ${ }^{\mathrm{b}}$, Francisco A. Leone ${ }^{\mathrm{a}, *}$ \\ a Departamento de Química, Faculdade de Filosofia, Ciências e Letras de Ribeirão Preto/USP, Brazil \\ ${ }^{\mathrm{b}}$ Departamento de Biologia -Faculdade de Filosofia, Ciências e Letras de Ribeirão Preto/USP, Brazil \\ ${ }^{\mathrm{c}}$ Universidade Estadual Paulista Júlio de Mesquita Filho - Campus de São José do Rio Preto, Brazil
}

\section{A R T I C L E I N F O}

\section{Article history:}

Received 26 June 2015

Received in revised form 28 October 2015

Accepted 29 October 2015

Available online 2 November 2015

\section{Keywords:}

Ammonia exposure

Gill microsome

$\left(\mathrm{Na}^{+}\right.$

$\mathrm{K}^{+}$-ATPase

$\mathrm{V}\left(\mathrm{H}^{+}\right)$-ATPase

Gene expression

Oxidative enzymes

Macrobrachium amazonicum

\begin{abstract}
A B S T R A C T
We evaluate the effects of total ammonia nitrogen-N (TAN) exposure for $72 \mathrm{~h}$ on $\left(\mathrm{Na}^{+}, \mathrm{K}^{+}\right)-$and $\mathrm{V}\left(\mathrm{H}^{+}\right)$ATPase activities and on their subunit expressions in gills of the diadromous freshwater shrimp Macrobrachium amazonicum. Specific $\left(\mathrm{Na}^{+}, \mathrm{K}^{+}\right)$- and $\mathrm{V}\left(\mathrm{H}^{+}\right)$-ATPase activities increased roughly 1.5- to 2fold, respectively, after exposure to $2.0 \mathrm{mmol} \mathrm{L}^{-1}$ TAN. Quantitative RT-PCR analyses revealed a 2.5-fold increase in $\mathrm{V}\left(\mathrm{H}^{+}\right)$-ATPase B subunit mRNA expression while $\left(\mathrm{Na}^{+}, \mathrm{K}^{+}\right)$-ATPase $\alpha$-subunit expression was unchanged. Immunohistochemical analyses of the gill lamellae located the $\left(\mathrm{Na}^{+}, \mathrm{K}^{+}\right)$-ATPase throughout the intralamellar septal cells, independently of TAN concentration, while the $\mathrm{V}\left(\mathrm{H}^{+}\right)$-ATPase was located in both the apical pillar cell flanges and pillar cell bodies. Systemic stress parameters like total hemocyte count decreased by $30 \%$ after exposure to $2.0 \mathrm{mmol} \mathrm{L}^{-1} \mathrm{TAN}$, accompanied by increased activities of the oxidative stress enzymes superoxide dismutase, glutathione reductase and glucose-6-phosphate dehydrogenase in the gills. The stress responses of $M$. amazonicum to elevated TAN include increases in gill $\left(\mathrm{Na}^{+}, \mathrm{K}^{+}\right)$- and $\mathrm{V}\left(\mathrm{H}^{+}\right)$-ATPase activities that are accompanied by changes in oxidative stress enzyme activities, immune system effects and an increase in gill $\mathrm{V}\left(\mathrm{H}^{+}\right)$-ATPase gene expression. These findings likely underpin physiological effects in a crustacean like $M$. amazonicum that exploits multiple ecosystems during its life cycle, as well as under culture conditions that may significantly impact shrimp production by the aquaculture industry.
\end{abstract}

(c) 2015 Elsevier B.V. All rights reserved.

\section{Introduction}

Ammonia, nitrate and nitrite are essential, life-sustaining, nitrogen-containing compounds used by many aquatic microorganisms. When ionized, such substances constitute the most common forms of dissolved inorganic nitrogen available to aquatic ecosystems. However, in excess, these ions affect the abundance, distribution and physiological responses of aquatic organisms, including decapod crustaceans. This is an issue that looms large when considering increasing global anthropic activities that augment nitrogen availability (Romano and Zeng, 2013; Camargo and Alonso, 2006).

\footnotetext{
* Corresponding author at: Departamento de Química-Faculdade de Filosofia, Ciências e Letras de Ribeirão Preto/Universidade de São Paulo. Avenida Bandeirantes 3900. 14040-901 Ribeirão Preto, SP. Brazil.

E-mail address: fdaleone@ffclrp.usp.br (F.A. Leone).
}

In aquatic environments, ammonia exists as $\mathrm{NH}_{4}{ }^{+}$and $\mathrm{NH}_{3}$, the latter being the more toxic form since it diffuses easily across plasma membranes and into the blood or hemolymph (Weihrauch et al., 2004a). The $\mathrm{NH}_{4}{ }^{+}: \mathrm{NH}_{3}$ ratio is strongly $\mathrm{pH}$-dependent and ammonia toxicity increases at higher $\mathrm{pH}$ since $\mathrm{NH}_{3}$ prevails over $\mathrm{NH}_{4}{ }^{+}$(Armstrong et al., 1978). While salinity and temperature exert a lesser effect on $\mathrm{NH}_{4}{ }^{+}: \mathrm{NH}_{3}$ ratios, ammonia toxicity is greatly influenced by these two important ambient parameters (Romano and Zeng, 2010; Lin and Chen, 2001). Like most aquatic animals, crustaceans are mainly ammoniotelic, and their nitrogenous metabolic end products are excreted principally in the form of ammonia; urea is a minor N-excretion product, accounting for $\approx 20 \%$ of total N-excretion (Weihrauch et al., 1999). The main sites of ammonia excretion in crustaceans are organs often involved in osmoregulatory ion transport such as the gills, pleiopods, and other well ventilated or perfused appendages (Romano and Zeng, 2013; O'Donnell, 1997). Although ammonia excretion in aquatic invertebrates has been considered a strictly passive process (Kormanik and 
Cameron, 1981), recent evidence shows that ammonia is excreted actively and, when necessary, against an inwardly directed gradient in marine, brackish and freshwater crustaceans (Weihrauch et al., 2004a). While exposure to ammonia affects ontogenesis, growth, gas exchange, acid-base balance and immunological responses, comprehensive reviews on the toxic effects of ammonia, their physiological consequences and adaptive mechanisms in the Crustacea are few (Romano and Zeng, 2013).

The $\left(\mathrm{Na}^{+}, \mathrm{K}^{+}\right)$-ATPase, a transport enzyme located basolaterally in epithelial cells, is a major effector of ammonia excretion in aquatic invertebrates (Weihrauch et al., 2009). This enzyme is the most prominent member of the P-type vertebrate ATPase family (Toyoshima et al., 2013; Chourasia and Sastry, 2012; Poulsen et al., 2010) and transports three $\mathrm{Na}^{+}$out of and two $\mathrm{K}^{+}$into the cell cytoplasm for each molecule of ATP hydrolyzed. Compared to the vertebrate enzyme, the structure of the crustacean gill $\left(\mathrm{Na}^{+}, \mathrm{K}^{+}\right)$ATPase is poorly known. However, like other $\left(\mathrm{Na}^{+}, \mathrm{K}^{+}\right)$-ATPases, it consists of an $\alpha$-subunit of 95-104 kDa $\mathrm{M}_{\mathrm{r}}$ (Leone et al., 2015; Lucena et al., 2012), a $\beta$-subunit of $38-40 \mathrm{kDa} \mathrm{M}_{\mathrm{r}}$ (Peterson and Hokin, 1981) and the FXYD peptide (Silva et al., 2012). Like the vertebrate enzyme, the crustacean $\left(\mathrm{Na}^{+}, \mathrm{K}^{+}\right)$-ATPase also exhibits highand low-affinity ATP binding sites (Lucena et al., 2012; Santos et al., 2007; Gonçalves et al., 2006; Masui et al., 2002). Relative to the maximum hydrolysis rate, the contribution of these two ATP binding sites is similar for both $\mathrm{Na}^{+}$and $\mathrm{K}^{+}$ions (Masui et al., 2002); however, there is a specific $\mathrm{K}^{+}$concentration at which the high affinity binding sites for ATP appear (Masui et al., 2008). Acclimation of a marine crab to low salinity causes the disappearance of the high affinity ATP binding sites (Masui et al., 2009). In crustaceans, the substitution of $\mathrm{K}^{+}$by $\mathrm{NH}_{4}{ }^{+}$sustains ATP hydrolysis (Leone et al., 2014; Towle and Holleland, 1987) as seen in the vertebrate enzyme (Skou and Esmann, 1992). However, synergistic stimulation of gill $\left(\mathrm{Na}^{+}, \mathrm{K}^{+}\right)$-ATPase activity by both $\mathrm{K}^{+}$and $\mathrm{NH}_{4}{ }^{+}$, a phenomenon seen in crustaceans alone, increases reaction rate by up to 1.5 -fold (Leone et al., 2014; França et al., 2013; Garçon et al., 2009; Masui et al., 2009; Gonçalves et al., 2006).

Membrane-associated $\mathrm{V}\left(\mathrm{H}^{+}\right)$-ATPase also plays an important role in gill ammonia excretion by means of an exocytic mechanism that involves the protonation of $\mathrm{NH}_{3}$ to $\mathrm{NH}_{4}{ }^{+}$via acidification of intracellular vesicles (Henry et al., 2012; Weihrauch et al., 2004a, 2002). In freshwater shrimps, the $\mathrm{V}\left(\mathrm{H}^{+}\right)$-ATPase is located in the apical region of the gill pillar cells (Lucena et al., 2015), while in crabs it may be found in cytoplasmic vesicles (Weihrauch et al., 2001). A novel, Rhesus-like ammonia transporter may translocate cytoplasmic $\mathrm{NH}_{3}$ into intracellular vesicles; however, detailed characteristics of this transporter are as yet unavailable (Henry et al., 2012; Weihrauch et al., 2009, 2004a). An apically-located cation $/ \mathrm{H}^{+}$ exchanger is another transporter likely involved in crustacean ammonia excretion (Henry et al., 2012). Trans- and/or paracellular diffusion of ammonia across the gill epithelium cannot be excluded (Henry et al., 2012; Weihrauch et al., 2009, 2004a).

Aquatic crustaceans lack an adaptive immune system and rely solely on various innate immune responses for protection against pathogens (Muta and Iwanaga, 1996). One important immunological response is hemocyte production by specialized hematopoietic tissue (Ellis et al., 2011; Johansson et al., 2000). Oxidative stress occurs in organisms when the production of reactive oxygen species (ROS) exceeds their rate of detoxification by antioxidant defense systems like antioxidant enzymes, leading to increased oxidative damage to different cellular targets (Kopecka-Pilarczyk and Correia, 2009; Almeida et al., 2007). While innate anti-oxidant mechanisms such as ROS scavenger enzymes remove ROS resulting from the immune response, elevated ambient ammonia levels reduce resistance to oxidative stress (Wang and Chen, 2005; Liu and Chen, 2004) and can impair oxygen consumption (Chen and Lin, 1992).
The Amazon river shrimp Macrobrachium amazonicum pertains to the family Palaemonidae, and occurs in tropical and subtropical regions of South America (Holthuis, 1952). This diadromous shrimp is primarily a freshwater species (Magalhães, 1985) that migrates to brackish water for spawning and is dependent on brackish water for larval development (McNamara et al., 1983). However, some populations have diversified into hololimnetic continental habitats like rivers, lakes and other inland water bodies (Hayd and Anger, 2013; Charmantier and Anger, 2011). Adult M. amazonicum is a strong hyperosmotic regulator in fresh water, including excellent chloride regulatory capability (Augusto et al., 2007). Considering that freshwater shrimp culture is a fast growing, global aquaculture activity, M. amazonicum is also cultivated in northern Brazil on a commercial scale (Marques and Moraes-Valenti, 2012). Given the presence of elevated ammonia titers, particularly under commercial aquaculture conditions, we propose the use of $M$. amazonicum as a convenient model in which to evaluate systemic, cellular and molecular responses to exposure in vivo to elevated ammonia concentrations.

In this study, we investigate ammonia toxicity in $M$. amazonicum, focusing particularly on gill $\left(\mathrm{Na}^{+}, \mathrm{K}^{+}\right)$- and $\mathrm{V}\left(\mathrm{H}^{+}\right)$-ATPase activities, localization and mRNA expression, and on selected oxidative stress enzymes and total hemocyte count. Our findings suggest that the stress responses of $M$. amazonicum to elevated ammonia are not limited to a simple increase in $\left(\mathrm{Na}^{+}, \mathrm{K}^{+}\right)$and $\mathrm{V}\left(\mathrm{H}^{+}\right)$-ATPase activities, but are accompanied by changes in oxidative stress enzyme activities, immune system effects and alterations in $\mathrm{V}\left(\mathrm{H}^{+}\right)$-ATPase gene expression.

\section{Materials and methods}

\subsection{Material}

All solutions were prepared using Millipore MilliQ ultrapure, apyrogenic water. Tris, ATP ditris salt, pyruvate kinase (PK), phosphoenolpyruvate (PEP), NADH, imidazole, $\mathrm{N}-(2-$ hydroxyethyl)piperazine-N19-ethanesulfonic acid(HEPES), lactate dehydrogenase (LDH), ouabain, 4',6-diamidino-2-phenylindole dyhydrochloride (DAPI), sodium orthovanadate, EDTA, 1-chloro2,4-dinitrobenzene, nicotinamide adenine dinucleotide phosphate (NADPH), glucose-6-phosphate (G6P), glutathione dissulfite (GSSG), bafilomycin $A_{1}$ and diethyl pyrocarbonate (DEPC) were purchased from the Sigma Chemical Company (Saint Louis, USA). Dimethyl sulfoxide (DMSO) and triethanolamine were from Merck (Darmstadt, Germany). The protease inhibitor cocktail ( $1 \mathrm{mmol} \mathrm{L}^{-1}$ benzamidine, $5 \mu \mathrm{mol} \mathrm{L}^{-1}$ antipain, $5 \mu \mathrm{mol} \mathrm{L}^{-1}$ leupeptin, $1 \mu \mathrm{mol} \mathrm{L}^{-1}$ pepstatin $A$ and $5 \mu \mathrm{mol} \mathrm{L}^{-1}$ phenylmethane-sulfonyl-fluoride) was from Calbiochem (Darmstadt, Germany). Mouse monoclonal IgG $\alpha-5$ antibody raised against chicken $\left(\mathrm{Na}^{+}, \mathrm{K}^{+}\right)$-ATPase $\alpha$-subunit, and mouse monoclonal IgG1 antibody (\#224-256-2) raised against the $c$-subunit of Dictyostelium discoideum $\mathrm{V}\left(\mathrm{H}^{+}\right)$-ATPase were purchased from the Development Studies Hybridoma Bank (Iowa, USA). Alexa-fluor 488 conjugated donkey anti-mouse IgG was from Invitrogen (Carlsbad, USA). Optimal Cutting Temperature Compound was from Sakura Tissue-Tek (Torrance, USA); Fluoromount-G and $p$ formaldehyde were purchased from Electron Microscopy Sciences (Hatfield, USA).

Crystalline suspensions of LDH and PK $(200 \mu \mathrm{L})$ were centrifuged at $20,000 \times g$ for $15 \mathrm{~min}$ at $4{ }^{\circ} \mathrm{C}$ in an Eppendorf 5810 refrigerated centrifuge (Hamburg, Germany) to remove ammonium sulfate. The pellet was resuspended in $500 \mu \mathrm{L}$ of $50 \mathrm{mmol} \mathrm{L}^{-1}$ HEPES buffer, pH 7.5, transferred to a YM-10 Microcon filter and washed five times at $14,000 \times g$ for $15 \mathrm{~min}$ at $4{ }^{\circ} \mathrm{C}$ in the same buffer until complete removal of ammonium ions (tested with the Nessler 
reagent). Finally, the pellet was resuspended to the original volume. Ammonium sulfate-depleted PK and LDH suspensions were used within two days. Stock solutions of ATP, bafilomycin $A_{1}$ and sodium orthovanadate were prepared according to Lucena et al. (2015). When necessary, enzyme solutions were concentrated on YM-10 Amicon Microcon filters.

\subsection{Shrimps}

Amazon river shrimps, $M$. amazonicum, were produced at the Aquaculture Center, UNESP, Jaboticabal, São Paulo, Brazil from broodstock collected in fresh water at Furo das Marinhas near Santa Bárbara do Pará ( $1^{\circ} 13^{\prime} 25^{\prime}$ S; $48^{\circ} 17^{\prime} 40^{\prime}$ W), northeastern Pará State, Brazil, in 2001 (Araujo and Valenti, 2007). Adult male shrimps of about $12.5 \mathrm{~cm}$ length and $\approx 13 \mathrm{~g}$ wet weight were collected from freshwater ponds and held briefly in carboys containing $32 \mathrm{~L}$ aerated pond water during transport.

Shrimps were used in stage $C$ of the intermolt cycle (Peebles, 1977). Before ammonia exposure, the shrimps were maintained for four days in aerated distilled water, at $28 \pm 3^{\circ} \mathrm{C}$ under a natural photoperiod (12 h: $12 \mathrm{~h}$ light:dark) and were fed once a day with shrimp tails.

\subsection{Exposure of shrimps to ammonia}

Groups of five shrimps each ( $N=5 /$ group, $\approx 3.3 \mathrm{~g}$ total wet gill mass/group) were transferred to three different tanks holding $60 \mathrm{~L}$ of distilled water containing different total ammonia-N (TAN) concentrations, for $72 \mathrm{~h}$. The TAN concentrations used were 0 (control), $0.9 \mathrm{mmol} \mathrm{L}^{-1}$ and $2.0 \mathrm{mmol} \mathrm{L}^{-1}$ total ammonia-N. The tanks were held at $28 \pm 3{ }^{\circ} \mathrm{C}$ using air conditioning, under a natural photoperiod ( $12 \mathrm{~h}: 12 \mathrm{~h}$ light:dark). The shrimps were fed once a day with shrimp tails. pH was monitored daily and was maintained at 7.2. Total ammonia- $\mathrm{N}$ levels were checked every $24 \mathrm{~h}$ and, when necessary, adjusted to each initial concentration. TAN concentration was tested using the ninhydrin reagent (Moore and Stein, 1954). TAN solutions were prepared by dissolving ammonium sulfate in aerated distilled water at the required concentrations. A general equation for bases (Eq. (1)) was used to calculate total ammonia-N concentration (Albert, 1973).

$\left[\mathrm{NH}_{3}\right]=\frac{\left[\mathrm{NH}_{3}+\mathrm{NH}_{4}^{+}\right]}{1+10^{\left(\mathrm{pK}_{\mathrm{a}}-\mathrm{pH}\right)}}$

\subsection{Sample preparation for microsomal $\left(\mathrm{Na}^{+}, \mathrm{K}^{+}\right)$-ATPase and $V\left(H^{+}\right)$-ATPase activities}

A microsomal fraction was prepared from the gills of each group of shrimps exposed for $72 \mathrm{~h}$ to each TAN concentration (control $=0 \mathrm{mmol} \mathrm{L}^{-1}, 0.9 \mathrm{mmol} \mathrm{L}^{-1}$ or $2.0 \mathrm{mmol} \mathrm{L}^{-1}$ total ammonia-N). The 5 shrimps in each group were anesthetized by chilling in crushed ice before gill dissection. After removal of the branchiostegites, all 7 gill pairs were rapidly dissected from each of the 5 shrimps, pooled (70 gills; total wet mass $\approx 3.3 \mathrm{~g}$ ), diced and homogenized in a Potter homogenizer (600 rpm) in $20 \mathrm{mmol} \mathrm{L}^{-1}$ imidazole buffer, pH 6.8, containing $6 \mathrm{mmol} \mathrm{L}^{-1}$ EDTA, $250 \mathrm{mmol} \mathrm{L}^{-1}$ sucrose and a protease inhibitor cocktail ( $20 \mathrm{~mL}$ buffer/g wet tissue). After centrifuging the crude extract at $20,000 \times \mathrm{g}$ for $35 \mathrm{~min}$ at $4{ }^{\circ} \mathrm{C}$, the supernatant was placed on crushed ice and the pellet was re-suspended in an equal volume of imidazole homogenization buffer. After further centrifugation as above, the two supernatants were gently pooled and centrifuged at $100,000 \times g$ and the microsomal pellet was homogenized in $20 \mathrm{mmol} \mathrm{L}^{-1}$ imidazole buffer, $\mathrm{pH} 6.8$, containing $6 \mathrm{mmol} \mathrm{L}^{-1}$ EDTA and $250 \mathrm{mmol} \mathrm{L}^{-1}$ sucrose ( $15 \mathrm{~mL}$ buffer $/ \mathrm{g}$ wet tissue). Finally, $0.5-\mathrm{mL}$ aliquots were rapidly frozen in liquid nitrogen and stored at $-20^{\circ} \mathrm{C}$. No appreciable loss of either $\mathrm{V}\left(\mathrm{H}^{+}\right)$-ATPase or $\left(\mathrm{Na}^{+}, \mathrm{K}^{+}\right)$-ATPase activity was seen after two-month's storage. When required, aliquots were thawed, placed on crushed ice and used immediately.

\subsection{Sample preparation for analysis of oxidative stress enzyme activities}

Approximately $100 \mathrm{mg}$ of fresh gill tissue was dissected from a single gill randomly chosen from each shrimp $(N=5)$ exposed for $72 \mathrm{~h}$ to each TAN concentration. The tissue was homogenized in $20 \mathrm{mmol} \mathrm{L}^{-1}$ Tris- $\mathrm{HCl}(\mathrm{pH} 7.5)$ buffer $(1: 4 \mathrm{w} / \mathrm{v})$ containing $0.5 \mathrm{~mol} \mathrm{~L}^{-1}$ sucrose, $0.15 \mathrm{~mol} \mathrm{~L}^{-1} \mathrm{KCl}, 1 \mathrm{mmol} \mathrm{L}^{-1} \mathrm{EDTA}, 1 \mathrm{mmol} \mathrm{L}^{-1}$ DTT, and $0.1 \mathrm{mmol} \mathrm{L}^{-1}$ phenyl-methane-sulfonyl-fluoride, and centrifuged at $9000 \times \mathrm{g}$ for $20 \mathrm{~min}$ at $4{ }^{\circ} \mathrm{C}$. The supernatant obtained was centrifuged at $50,000 \times g$ for $60 \mathrm{~min}$ at $4{ }^{\circ} \mathrm{C}$, and the activities of superoxide dismutase (SOD), glutathione S-transferase (GST), glutathione reductase (GR) and glucose-6-phosphate dehydrogenase (G6PDH) were analyzed in the cytosolic fraction.

\subsection{Measurement of gill microsomal $\left(\mathrm{Na}^{+}, \mathrm{K}^{+}\right)$-ATPase activity}

Total ATPase activity was assayed at $25^{\circ} \mathrm{C}$ using a PK/LDH coupling system in which ATP hydrolysis was coupled to NADH oxidation according to Leone et al. (2014). The oxidation of NADH was monitored at $340 \mathrm{~nm}\left(\epsilon_{340 \mathrm{~nm}, \mathrm{pH} 7.5}=6200 \mathrm{~mol}^{-1} \mathrm{~L} \mathrm{~cm}^{-1}\right)$ in a Hitachi U-3000 spectrophotometer equipped with thermostatted cell holders. Standard conditions were $50 \mathrm{mmol} \mathrm{L}^{-1} \mathrm{HEPES}$ buffer, $\mathrm{pH} 7.5,2 \mathrm{mmol} \mathrm{L}^{-1}$ ATP, containing $5 \mathrm{mmol} \mathrm{L}^{-1} \mathrm{MgCl}_{2}, 20 \mathrm{mmol} \mathrm{L}^{-1}$ $\mathrm{NaCl}, 20 \mathrm{mmol} \mathrm{L}^{-1} \mathrm{KCl}, 0.14 \mathrm{mmol} \mathrm{L}^{-1} \mathrm{NADH}, 2 \mathrm{mmol} \mathrm{L}^{-1} \mathrm{PEP}, 82 \mu \mathrm{g}$ PK (49U) and $110 \mu \mathrm{g}$ LDH (94U) in a final volume of $1 \mathrm{~mL}$. ATP hydrolysis was also estimated using $3 \mathrm{mmol} \mathrm{L}^{-1}$ ouabain to assess ouabain-insensitive activity. The difference in measured activity in the absence (total ATPase activity) or presence of ouabain (ouabain-insensitive activity) was considered to represent the $\left(\mathrm{Na}^{+}, \mathrm{K}^{+}\right)$-ATPase activity. ATPase activity was also assayed after 10 min pre-incubation at $25^{\circ} \mathrm{C}$ with alamethicin ( $1 \mathrm{mg} / \mathrm{mg}$ protein) as a control for leaky and/or disrupted vesicles. Controls without added enzyme were included in each experiment to quantify the non-enzymatic hydrolysis of substrate. Initial velocities were constant for at least for 15 min provided that less than $5 \%$ of the total NADH was oxidized. The reaction rate was estimated in triplicate using identical aliquots from each homogenate. For each microsomal preparation, assay linearity was checked using samples containing from 5 to $50 \mu \mathrm{g}$ protein, and total microsomal protein added to the cuvette was within the linear range of the assay. Neither NADH, PEP, LDH nor PK was rate limiting over the initial course of the assay and no activity was measurable in the absence of NADH. The data provided for each ATP saturation curve are the mean values obtained for microsomal fractions prepared from two replicate TAN exposure experiments. For each ATP concentration, reaction rates were estimated using duplicate aliquots repeated three times for each replicate microsomal preparation. One enzyme unit (U) is defined as the amount of enzyme hydrolyzing $1.0 \mathrm{nmol}$ of ATP per minute at $25^{\circ} \mathrm{C}$, and specific activity is given as nmol $\mathrm{P}_{\mathrm{i}} \mathrm{min}^{-1} \mathrm{mg}$ protein $^{-1}$.

\subsection{Measurement of gill microsomal $V\left(H^{+}\right)$-ATPase activity}

$\mathrm{V}\left(\mathrm{H}^{+}\right)$-ATPase activity was assayed at $25^{\circ} \mathrm{C}$ using a PK/LDH coupling system in which ATP hydrolysis was coupled to NADH oxidation according to Lucena et al. (2015). NADH oxidation was monitored at $340 \mathrm{~nm}\left(\epsilon_{340 \mathrm{~nm}}, \mathrm{pH} 7.5=6200 \mathrm{~mol} \mathrm{~L}^{-1} \mathrm{~cm}^{-1}\right)$ in a Hitachi U-3000 spectrophotometer equipped with thermostatted cell holders. Standard assay conditions for estimation of total microsomal P-ATPase activity were $50 \mathrm{mmol} \mathrm{L}^{-1}$ HEPES buffer, $\mathrm{pH} 7.5$, containing $2 \mathrm{mmol} \mathrm{L}^{-1}$ ATP, $5 \mathrm{mmol} \mathrm{L}^{-1} \mathrm{MgCl}_{2}, 20 \mathrm{mmol} \mathrm{L}^{-1} \mathrm{KCl}$, 
Table 1

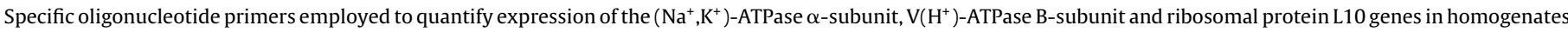

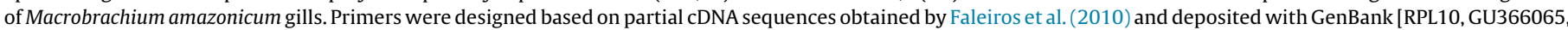
$\left(\mathrm{Na}^{+}, \mathrm{K}^{+}\right)$-ATPase GQ329698, V( $\left.\mathrm{H}^{+}\right)$-ATPase GQ329699].

\begin{tabular}{|c|c|c|}
\hline Primer & Nucleotide sequence $\left(5^{\prime}-3^{\prime}\right)$ & Amplicon (bp) \\
\hline \multicolumn{3}{|l|}{$\left(\mathrm{Na}^{+}, \mathrm{K}^{+}\right)$-ATPase } \\
\hline Specific sense primer NaK_Pal_F & TGCGAGATTCCCTTCAATTC & 108 \\
\hline Specific antisense primer NaK_Pal_R & TCTCTCTGGAGCTCCСTTCA & \\
\hline \multicolumn{3}{|l|}{$V\left(H^{+}\right)$-ATPase } \\
\hline Specific sense primer V_Pal_F & ACGATCCCACAATTGAACGT & 143 \\
\hline Specific antisense primer V_Pal_R & AGCAGATACCTCTCGCAAAG & \\
\hline \multicolumn{3}{|c|}{ Ribosomal protein L10 (endogenous control) } \\
\hline Specific sense primer RPL10_Pal_F & ATGGGCTGACCAATTCTTACAC & 85 \\
\hline Specific sense primer RPL10_Pal_R & GTGCTGATAGATTGCAGACAGG & \\
\hline
\end{tabular}

$50 \mu \mathrm{mol} \mathrm{L}^{-1}$ orthovanadate, $0.14 \mathrm{mmol} \mathrm{L}^{-1} \mathrm{NADH}, 2.0 \mathrm{mmol} \mathrm{L}^{-1}$ PEP, $82 \mu \mathrm{g}$ PK (49U) and $110 \mu \mathrm{g}$ LDH (94U) in a final volume of $1.0 \mathrm{~mL}$. Microsomal $\mathrm{V}\left(\mathrm{H}^{+}\right)$-ATPase activity was estimated by firstly measuring total ATPase activity with $50 \mu \mathrm{mol} \mathrm{L}^{-1}$ orthovanadate (orthovanadate-insensitive ATPase activity) and then with $50 \mu \mathrm{mol} \mathrm{L}^{-1}$ orthovanadate plus $4 \mu \mathrm{mol} \mathrm{L}^{-1}$ bafilomycin $\mathrm{A}_{1}$ (bafilomycin-insensitive ATPase activity). The difference in activities measured with (bafilomycin-insensitive ATPase activity) and without bafilomycin $A_{1}$ (orthovanadate-insensitive ATPase activity) was considered to represent $\mathrm{V}\left(\mathrm{H}^{+}\right)$-ATPase activity. The data provided in each ATP saturation curve are the mean values obtained for microsomal fractions prepared from two replicate TAN exposure experiments. For each ATP concentration, reaction rates were estimated using duplicate aliquots repeated three times for each replicate microsomal preparation. One enzyme unit (U) is defined as the amount of enzyme hydrolyzing $1.0 \mathrm{nmol}$ of ATP per minute at $25^{\circ} \mathrm{C}$, and specific activity is given as nmol $\mathrm{P}_{\mathrm{i}} \mathrm{min}^{-1} \mathrm{mg}$ protein ${ }^{-1}$.

\subsection{Assays of oxidative enzyme activities}

Superoxide dismutase (SOD) activity was evaluated according to McCord and Fridovich (1969), based on the inhibition of cytochrome $\mathrm{c}$ reduction at $550 \mathrm{~nm}$ elicited by the superoxide anion coupled to the xanthine/xanthine oxidase system. One SOD unit is defined as the amount of enzyme that provides $50 \%$ inhibition of cytochrome c reduction at $25^{\circ} \mathrm{C}$. Glutathione S-transferase (GST) activity was estimated by measuring the increase in absorbance at $340 \mathrm{~nm}\left(\epsilon_{340 \mathrm{~nm}}\right.$, pH6.5 $\left.=9600 \mathrm{~mol}^{-1} \mathrm{~L} \mathrm{~cm}^{-1}\right)$, incubating reduced glutathione (GSH) and 1-chloro-2, 4-dinitrobenzene (Keen et al., 1976). Glutathione reductase (GR) activity was estimated according to Carlberg and Mannervick (1985), based on the oxidation of glutathione disulfide by NADPH $\left(\epsilon_{340 \mathrm{~nm}}, \mathrm{pH} 7.5=6220 \mathrm{~mol}^{-1} \mathrm{~L} \mathrm{~cm}^{-1}\right)$, at $\mathrm{pH} 7.5$ and $30^{\circ} \mathrm{C}$. Glucose-6-phosphate dehydrogenase (G6PDH) activity was estimated by measuring the increase in absorbance at $340 \mathrm{~nm}\left(\epsilon_{340 \mathrm{~nm}}, \mathrm{pH} 7.4=6220 \mathrm{~mol}^{-1} \mathrm{~L} \mathrm{~cm}^{-1}\right)$, incubating NADP and glucose-6-phosphate according to Glock and Mc (1953). Enzyme activity is given as micromoles NADPH $\mathrm{min}^{-1} \mathrm{mg}_{\text {protein }}{ }^{-1}$.

\subsection{Immunolocalization of the gill $\left(\mathrm{Na}^{+}, \mathrm{K}^{+}\right)$-ATPase and $V\left(H^{+}\right)$-ATPase}

Fourth, right side gills were dissected and incubated in a fixative solution containing $2 \% p$-formaldehyde in a phosphate buffered saline (PBS, $\mathrm{Na}_{2} \mathrm{HPO}_{4} 10 \mathrm{mmol} \mathrm{L}^{-1}, \mathrm{KH}_{2} \mathrm{PO}_{4} 2 \mathrm{mmol} \mathrm{L}^{-1}$, $\left.\mathrm{NaCl} 137 \mathrm{mmol} \mathrm{L}^{-1}, \mathrm{KCl} 2.7 \mathrm{mmol} \mathrm{L}^{-1}, 290 \mathrm{mOsm} \mathrm{kg} \mathrm{H}^{-1} \mathrm{O}\right), \mathrm{pH}$ 7.4, for $1 \mathrm{~h}$, then embedded in Optimal Cutting Temperature Compound. $10-\mu \mathrm{m}$ thick cryosections were taken transversely to the gill lamellae long-axes at $-25^{\circ} \mathrm{C}$ using a Microm HM 505E Cryostatic Microtome (Walldorf, Germany) and collected on gelatin coated slides (Bloom 225). Cryosections were preincubated for $20 \mathrm{~min}$ with $100 \mathrm{mmol} \mathrm{L}^{-1}$ glycine in PBS and then for $10 \mathrm{~min}$ in blocking

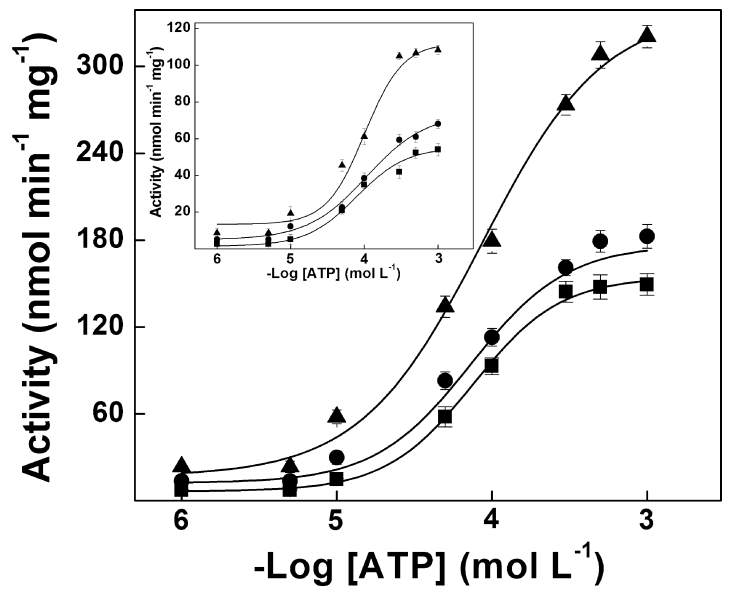

Fig. 1. Effect of ATP on microsomal $\left(\mathrm{Na}^{+}, \mathrm{K}^{+}\right)$-ATPase activity in the gills of $M$ amazonicum after 72-h exposure in vivo to different total ammonia-N (TAN) concentrations.

$\left(\mathrm{Na}^{+}, \mathrm{K}^{+}\right)$-ATPase activity was assayed continuously at $25^{\circ} \mathrm{C}$, in $50 \mathrm{mmol} \mathrm{L}-1$ HEPES buffer, $\mathrm{pH} 7.5$, as described in Section 2, and the reaction was started by the addition of $32 \mu \mathrm{g}$ protein. The data provided are mean values obtained from duplicate assays of three microsomal fractions from each of two replicate TAN exposure experiments (70 gills/TAN concentration). Inset: ouabain-insensitive ATPase activity. Control 0

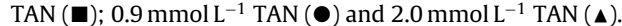

solution containing $1 \%$ bovine serum albumin and $0.1 \%$ gelatin in PBS. $\left(\mathrm{Na}^{+}, \mathrm{K}^{+}\right)$-ATPase $\alpha$-subunit and $\mathrm{V}\left(\mathrm{H}^{+}\right)$-ATPase c-subunit were immunolocalized according to França et al. (2013) and Lucena et al. (2015), respectively. To locate nuclei, sections were stained for 20 min with DAPI, diluted 1:200 in PBS. Sections were mounted in Fluoromount-G slide-mounting medium on Knittel Starfrost slides with cover slips (Bielefeld, Germany). They were observed and photographed using an Olympus BX-50 fluorescence microscope (Olympus America Inc., Melville, NY, USA) equipped with a SPOT RT3 25.42 Mb Slider camera (SPOT ${ }^{\mathrm{TM}}$ Imaging Solutions Inc., Sterling Heights, USA) employing differential interference contrast microscopy and excitation/emission wavelengths of $358 / 461 \mathrm{~nm}$ (DAPI) and 495/519 nm (Alexa-fluor 488).

\subsection{Total hemocyte count}

A hemolymph sample of $300 \mu \mathrm{L}$ was drawn from the base of the third pereiopod from each of the five individual shrimps $(N=5)$ in each TAN concentration using a 25 -gauge needle and $1-\mathrm{mL}$ sterile syringe containing $300 \mu \mathrm{L}$ of anticoagulant solution $\left(10 \mathrm{mmol} \mathrm{L}^{-1}\right.$

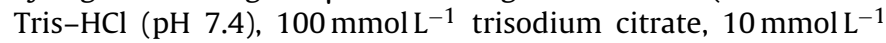
EDTA, $82 \mathrm{mmol} \mathrm{L}^{-1}$ glucose, $20 \mathrm{mmol} \mathrm{L}^{-1}$ sodium chloride, osmolality $420 \mathrm{mOsm} \mathrm{kg}^{-1}$ ). The total number of hemocytes in the diluted hemolymph from each sample was estimated three times using a hemocytometer and compound microscope (Nikon Eclipse TS100, Nikon USA, Melville, NY). 
Table 2

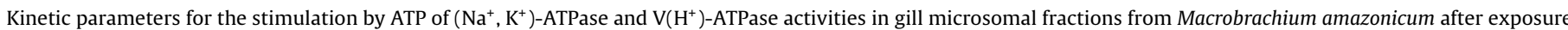

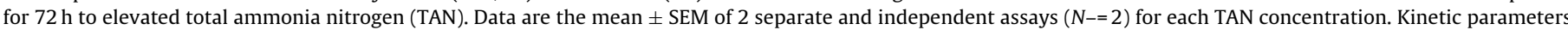
were estimated using duplicate aliquots repeated three times for each microsomal preparation.

\begin{tabular}{|c|c|c|c|c|c|c|}
\hline \multirow[b]{2}{*}{ TAN $\left(\mathrm{mmol} \mathrm{L}^{-1}\right)$} & \multicolumn{2}{|c|}{$\left(\mathrm{Na}^{+}, \mathrm{K}^{+}\right)$-ATPase } & \multirow[b]{2}{*}{$n_{\mathrm{H}}$} & \multicolumn{3}{|c|}{$\mathrm{V}\left(\mathrm{H}^{+}\right)$-ATPase } \\
\hline & $\mathrm{V}\left(\mathrm{U} \mathrm{mg}^{-1}\right)$ & $\mathrm{K}_{0.5}$ or $\mathrm{K}_{\mathrm{M}}\left(\mathrm{mmol} \mathrm{L}^{-1}\right)$ & & $\mathrm{V}\left(\mathrm{U} \mathrm{mg}^{-1}\right)$ & $\mathrm{K}_{0.5}$ or $\mathrm{K}_{\mathrm{M}}\left(\mathrm{mmol} \mathrm{L}^{-1}\right)$ & $n_{\mathrm{H}}$ \\
\hline 0 & $145.5 \pm 7.2$ & $0.07 \pm 0.002$ & 1.8 & $42.7 \pm 1.3$ & $2.3 \pm 0.07$ & 1.1 \\
\hline 0.9 & $168.1 \pm 8.4$ & $0.06 \pm 0.001$ & 1.4 & $54.4 \pm 1.6$ & $2.7 \pm 0.08$ & 1.1 \\
\hline 2.0 & $316.9 \pm 15.8$ & $0.08 \pm 0.002$ & 1.2 & $62.3 \pm 1.8$ & $2.8 \pm 0.08$ & 0.8 \\
\hline
\end{tabular}

Before exposure to the different TAN concentrations, five shrimps maintained for four days in aerated distilled water were chosen randomly and hemolymph was collected for total hemocyte count (THC). This mean value was considered to be the initial hemocyte count (time $=0$ ). Subsequently, the remaining shrimps were divided into three groups of five animals each and exposed to different TAN concentrations for $72 \mathrm{~h}$ as described above.

\subsection{Quantitative gene expression in gill homogenates}

Total RNA was extracted from a single gill from each of five different shrimps $(N=5)$ at each TAN concentration, under RNAsefree conditions, using Trizol reagent (Thermo Fisher Scientific, Life Technologies, Carlsbad, USA) according to the manufacturer's instructions. Total RNA was resuspended with ultrapure DEPCtreated water, quantified using a Qubit 2.0 fluorometer (Thermo Fisher Scientific, Life Technologies) and stored at $-80^{\circ} \mathrm{C}$. Reverse transcription was performed using $1 \mu \mathrm{g}$ DNAse I-treated total RNA employing SuperScript III Reverse Transcriptase (Life Technologies) following the manufacturer's instructions. PCR assays were performed in a Veriti ${ }^{\circledR}$ 96-Well Thermal Cycler (Thermo Fisher Scientific, Applied Biosystems).

Quantitative PCR assays were performed employing a 7500 Real Time PCR System (Thermo Fisher Scientific, Applied Biosystems) using Power SYBR ${ }^{\circledR}$ Green PCR Master Mix (Thermo Fisher Scientific, Life Technologies) according to the manufacturer's instructions. The thermocycling procedure consisted of an initial step at $95^{\circ} \mathrm{C}$ for $10 \mathrm{~min}$, followed by 40 cycles at $95^{\circ} \mathrm{C}$ for $15 \mathrm{~s}$ each, and a final step at $60^{\circ} \mathrm{C}$ for $1 \mathrm{~min}$. The RPL10 gene that encodes for ribosomal protein L10 was used as an endogenous control against which the expression values for the $\left(\mathrm{Na}^{+}, \mathrm{K}^{+}\right)$-ATPase $\alpha$-subunit and $\mathrm{V}\left(\mathrm{H}^{+}\right)$-ATPase B-subunit were normalized. Specific primers for quantifying expression of the RPL10, $\left(\mathrm{Na}^{+}, \mathrm{K}^{+}\right)$-ATPase $\alpha$-subunit and $\mathrm{V}\left(\mathrm{H}^{+}\right)$-ATPase B-subunit genes (Table 1 ) were designed based on partial cDNA sequences originally obtained by Faleiros et al. (2010), and deposited with GenBank (RPL10 accession number GU366065, $\left(\mathrm{Na}^{+}, \mathrm{K}^{+}\right)$-ATPase accession number GQ329698, and $\mathrm{V}\left(\mathrm{H}^{+}\right)$-ATPase accession number GQ329699).

Quantitative PCR assays were repeated three times for each of the five gill preparations at each TAN concentration. For relative quantification of target gene expression, the comparative CT method was used (Pfaffl, 2001), employing the CT values for the three replicate samples. Sample $\Delta C T$ values were obtained by subtracting the target gene $\mathrm{CT}$ values for each individual gill sample from its respective CT value for RPL10 expression in the same sample. Relative transcript quantities were then calculated using the mean $\Delta \mathrm{CT}$ value from the five individual gill replicates for the control exposure $\left(0 \mathrm{mmol} \mathrm{L}^{-1}\right.$ total ammonia-N) as the calibrating value. The amount of target gene expression, normalized to the endogenous reference gene (RPL10) and relative to the calibrator value (control), is given by the formula $2^{-\Delta \Delta C T}$ (Livak and Schmittgen, 2001). Values for $\left(\mathrm{Na}^{+}, \mathrm{K}^{+}\right)$-ATPase expression have been calibrated against the control value for $\mathrm{V}\left(\mathrm{H}^{+}\right)$-ATPase expression.

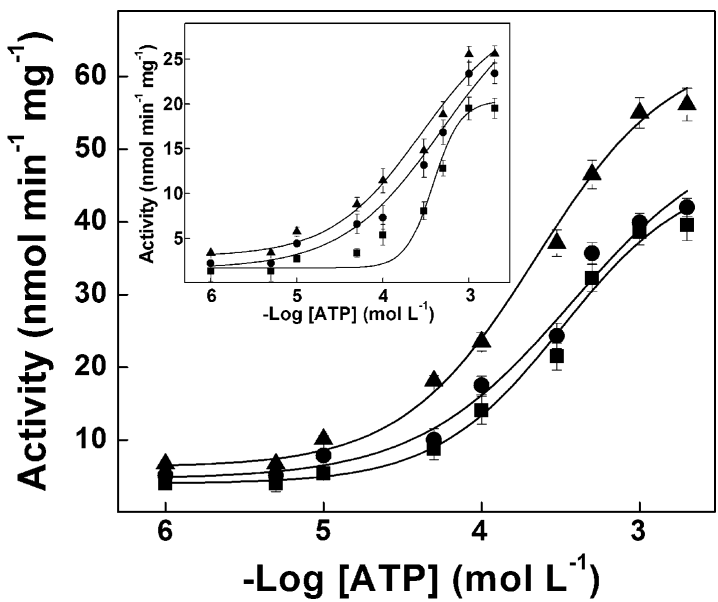

Fig. 2. Effect of ATP on microsomal $\mathrm{V}\left(\mathrm{H}^{+}\right)$-ATPase activity in gills of $M$. amazonicum after 72-h exposure in vivo to different total ammonia-N (TAN) concentrations. $\mathrm{V}\left(\mathrm{H}^{+}\right)$-ATPase activity was assayed continuously at $25^{\circ} \mathrm{C}$, in $50 \mathrm{mmol} \mathrm{L}^{-1} \mathrm{HEPES}$ buffer, $\mathrm{pH} 7.5$, and the reaction was started by the addition of $32 \mu \mathrm{g}$ protein. The data provided are mean values obtained from duplicate assays of three microsomal fractions from each of two replicate TAN exposure experiments (70 gills/TAN concentration). Inset: bafilomycin-insensitive ATPase activity. Control 0 TAN ( $\mathbf{\square})$; $0.9 \mathrm{mmol} \mathrm{L}^{-1} \mathrm{TAN}(\bullet)$ and $2.0 \mathrm{mmol} \mathrm{L}^{-1} \mathrm{TAN}(\boldsymbol{\Delta})$

\subsection{Protein measurement}

Total protein concentrations in samples for microsomal and oxidative stress enzymes were estimated according to Read and Northcote (1981) and Bradford (1976), respectively, using bovine serum albumin as the standard.

\subsection{Estimation of kinetic parameters}

The kinetic parameters for $V_{\mathrm{M}}$ (maximum velocity), $K_{0.5}$ (apparent dissociation constant), $K_{\mathrm{M}}$ (Michaelis-Menten constant) and the $n_{\mathrm{H}}$ (Hill coefficient) values for ATP hydrolysis were calculated using SigrafW software (Leone et al., 2005). The kinetic parameters given in the tables are calculated values and represent the mean \pm SEM derived from two $(N=2)$ independent microsomal preparations. SigrafW is freely available from http://portal.ffclrp. usp.br/sites/fdaleone/downloads

\subsection{Statistical analyses}

Relative mRNA expressions, total hemolymph hemocyte counts, and oxidative enzyme activities were analyzed using a one-way analysis of variance (main factor, total ammonia-N concentration). The Student-Newman-Keuls multiple means procedure was then used to locate different groups. Effects and differences were considered significant at $P \leq 0.05$. Results are expressed as the mean \pm SEM. 

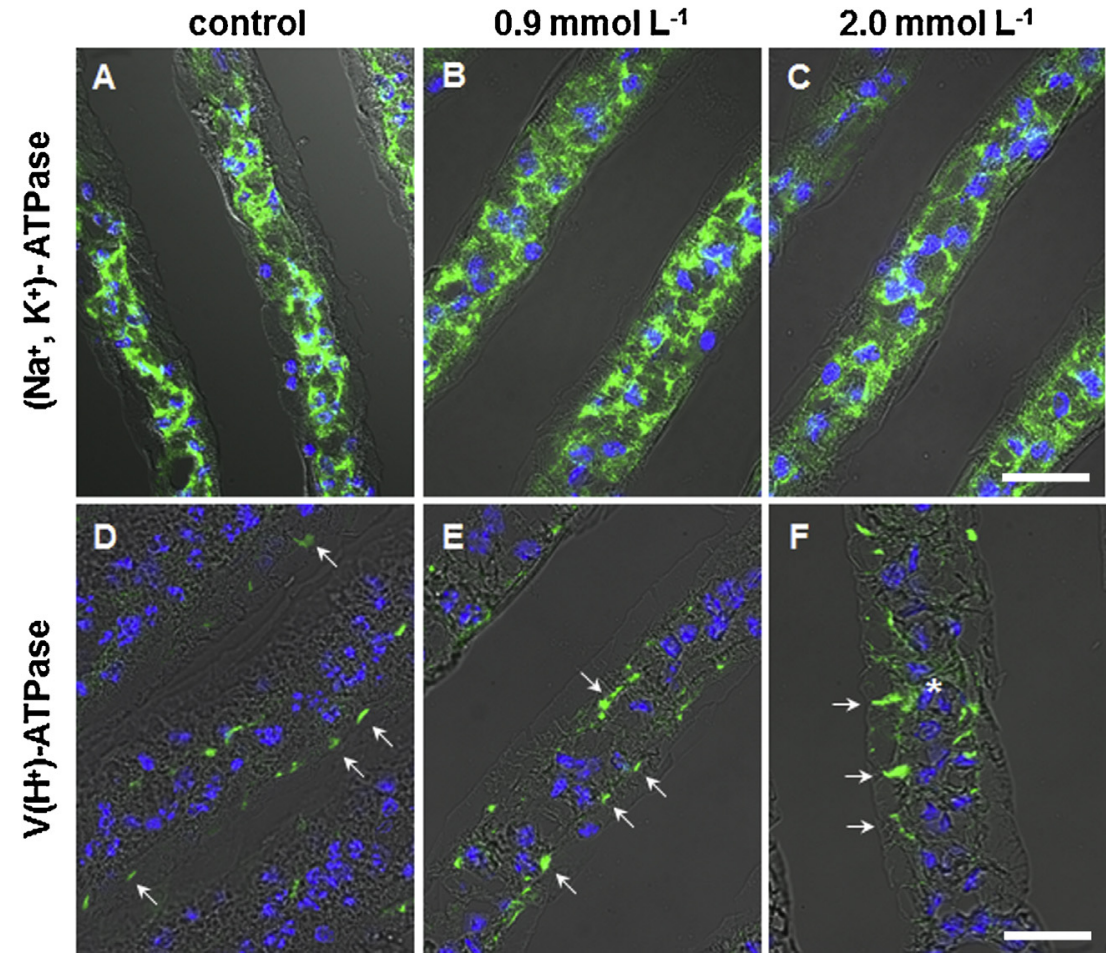

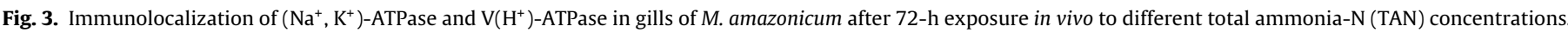

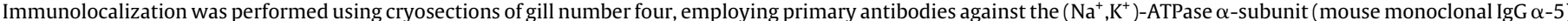

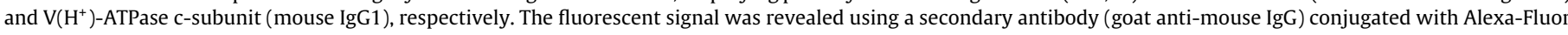

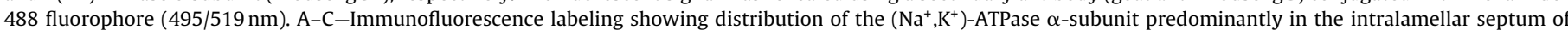

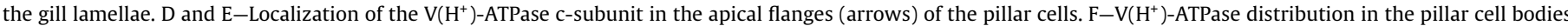

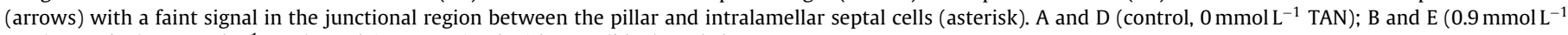
TAN); $C$ and F (2.0 $\mathrm{mmol} \mathrm{L}^{-1} \mathrm{TAN}$ ). Nuclei were stained with DAPI (blue). Scale bars $=50 \mu \mathrm{m}$.

\section{Results}

\subsection{Gill $\left(\mathrm{Na}^{+}, \mathrm{K}^{+}\right)$-ATPase activity}

Under saturating $\mathrm{K}^{+}\left(10 \mathrm{mmol} \mathrm{L}^{-1}\right), \mathrm{Na}^{+}\left(50 \mathrm{mmol} \mathrm{L}^{-1}\right)$ and $\mathrm{Mg}^{2+}\left(5 \mathrm{mmol} \mathrm{L}^{-1}\right)$ concentrations, ATP hydrolysis (Fig. 1) followed a single saturation curve over the range of $10^{-6} \mathrm{~mol} \mathrm{~L}^{-1}$ to $2 \times 10^{-3} \mathrm{~mol} \mathrm{~L}^{-1}$ ATP, independently of TAN concentration. At $0.9 \mathrm{mmol} \mathrm{L}^{-1}$ TAN, ATP was hydrolyzed at a maximum rate of $V_{\mathrm{M}}=168.1 \pm 8.4 \mathrm{nmol} \mathrm{P}_{\mathrm{i}} \mathrm{min}^{-1} \mathrm{mg}^{-1}$ with $K_{0.5}=0.06 \pm 0.001 \mathrm{mmol} \mathrm{L}^{-1} \quad\left(n_{\mathrm{H}}=1.4\right.$, Table 2). At $2.0 \mathrm{mmol} \mathrm{L}^{-1}$ TAN there was a noticeable increase in ATP hydrolysis with a maximum rate of $V_{\mathrm{M}}=316.9 \pm 15.8 \mathrm{nmol} \mathrm{P}_{\mathrm{i}} \mathrm{min}^{-1} \mathrm{mg}^{-1}$ and $K_{0.5}=0.08 \pm 0.002 \mathrm{mmol} \mathrm{L}^{-1} \quad\left(n_{\mathrm{H}}=1.2\right.$, Table 2). Compared to control shrimps $\left(V_{\mathrm{M}}=145.5 \pm 7.2 \mathrm{nmol} \mathrm{P}_{\mathrm{i}} \mathrm{min}^{-1} \mathrm{mg}^{-1}\right.$, $K_{0.5}=0.07 \pm 0.002 \mathrm{mmol} \mathrm{L}^{-1}$ and $n_{\mathrm{H}}=1.8$, Table 2), increasing TAN concentration increased $V_{\mathrm{M}}$ but did not affect $K_{0.5}$. Ouabaininsensitive ATPase activity increased from $\approx 50 \mathrm{nmol} \mathrm{Pi} \mathrm{min}^{-1} \mathrm{mg}^{-1}$

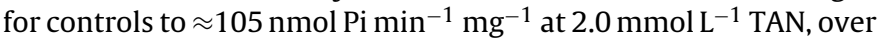
the same ATP concentration range (inset to Fig. 1).

\subsection{Gill $V\left(H^{+}\right)$-ATPase activity}

Under saturating $\mathrm{K}^{+}\left(10 \mathrm{mmol} \mathrm{L}^{-1}\right)$ and $\mathrm{Mg}^{2+}\left(2 \mathrm{mmol} \mathrm{L}^{-1}\right)$ concentrations, and in the presence of $50 \mu \mathrm{mol} \mathrm{L}^{-1}$ orthovanadate, ATP hydrolysis (Fig. 2) showed a well-defined saturation curve over the range of $10^{-6} \mathrm{~mol} \mathrm{~L}^{-1}$ to $2 \times 10^{-3} \mathrm{~mol} \mathrm{~L}^{-1}$ ATP, independently of TAN concentration. In shrimps exposed to $0.9 \mathrm{mmol} \mathrm{L}^{-1}$ or $2.0 \mathrm{mmol} \mathrm{L}^{-1}$ TAN, maximum hydrolysis rates were $V_{\mathrm{M}}=54.4 \pm 1.6 \mathrm{nmol} \mathrm{P}_{\mathrm{i}} \mathrm{min}^{-1} \mathrm{mg}^{-1}$ with $K_{\mathrm{M}}=2.7 \pm 0.08 \mathrm{mmol} \mathrm{L}^{-1}$ and $V_{\mathrm{M}}=62.3 \pm 1.8 \mathrm{nmol} \mathrm{P}_{\mathrm{i}} \mathrm{min}^{-1} \mathrm{mg}^{-1}$ with $K_{\mathrm{M}}=2.8 \pm 0.08 \mathrm{mmol} \mathrm{L}^{-1}$, respectively (Table 2). Independently of TAN concentration, the gill $\mathrm{V}\left(\mathrm{H}^{+}\right)$-ATPase hydrolyzed ATP obeying Michaelis-Menten kinetics. Compared to control shrimps $\left(V_{\mathrm{M}}=42.7 \pm 1.3 \mathrm{nmol} \mathrm{P}_{\mathrm{i}} \mathrm{min}^{-1} \mathrm{mg}^{-1}\right.$ with $K_{\mathrm{M}}=2.3 \pm 0.07 \mathrm{mmol} \mathrm{L}^{-1}$, Table 2), exposure of shrimps to different TAN concentrations increased $V_{\mathrm{M}}$ but did not affect $K_{0.5}$, a finding more evident at $2.0 \mathrm{mmol} \mathrm{L}^{-1}$ TAN. The bafilomycin-insensitive ATPase activities were $18.8 \mathrm{nmol} \mathrm{Pi} \mathrm{min}{ }^{-1} \mathrm{mg}^{-1}, 14.0 \mathrm{nmol} \mathrm{Pi} \mathrm{min}{ }^{-1} \mathrm{mg}^{-1}$ and

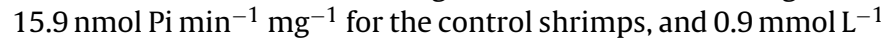
and $2.0 \mathrm{mmol} \mathrm{L}^{-1}$ TAN concentrations, respectively (inset to Fig. 2)

\subsection{Immunolocalization of gill $\left(\mathrm{Na}^{+}, \mathrm{K}^{+}\right)$-ATPase and $V\left(H^{+}\right)$-ATPase}

Immunofluorescence labeling of the $\left(\mathrm{Na}^{+}, \mathrm{K}^{+}\right)$-ATPase in shrimps exposed to different TAN concentrations for $72 \mathrm{~h}$ demonstrates that this enzyme is distributed exclusively throughout the intralamellar septum in the gill lamellae (Fig. $3 \mathrm{~A}-\mathrm{C}$ ). There are no notable differences in signal intensity with increasing TAN concentration. The $\mathrm{V}\left(\mathrm{H}^{+}\right)$-ATPase is located predominantly in the apical region of the gill pillar cells (Figs. 3D and E). However, in $2.0 \mathrm{mmol} \mathrm{L}^{-1}$ TAN (Fig. 3F), the fluorescent signal becomes dispersed throughout the entire pillar cell bodies and at their junction with the intralamellar septal cells.

\subsection{Quantitative expression of gill $\left(\mathrm{Na}^{+}, \mathrm{K}^{+}\right)$-ATPase and $V\left(H^{+}\right)$-ATPase $m R N A$}

$\left(\mathrm{Na}^{+}, \mathrm{K}^{+}\right)$-ATPase $\alpha$-subunit mRNA expression in the gills of shrimps exposed to increasing TAN concentrations for $72 \mathrm{~h}$ was unaffected $(P=0.745)$ (Fig. 4). However, $\mathrm{V}\left(\mathrm{H}^{+}\right)$-ATPase B-subunit 


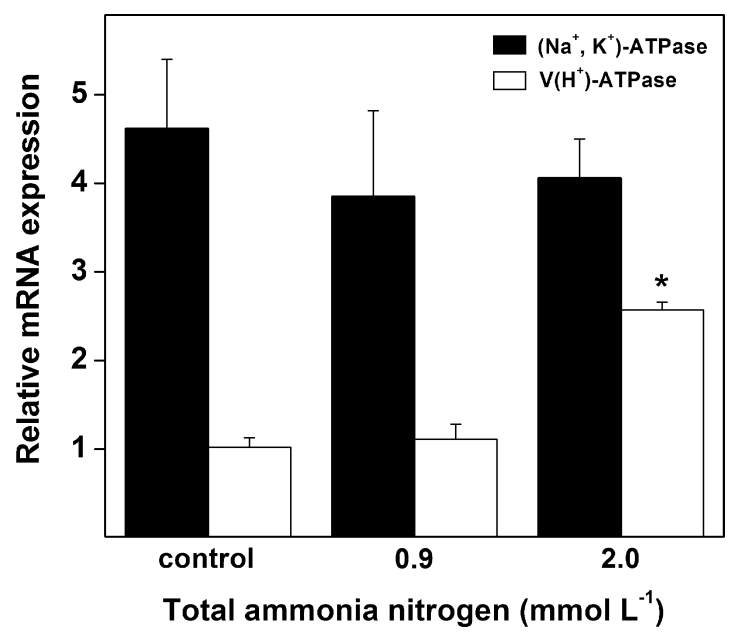

Fig. 4. Effect of exposure to different total ammonia-N (TAN) concentrations for $72 \mathrm{~h}$ in vivo on relative expression of gill $\left(\mathrm{Na}^{+}, \mathrm{K}^{+}\right)$-ATPase and $\mathrm{V}\left(\mathrm{H}^{+}\right)$-ATPase subunits in M. amazonicum.

Relative expression of mRNA for the $\left(\mathrm{Na}^{+}, \mathrm{K}^{+}\right)$-ATPase $\alpha$-subunit (black bars) and the $\mathrm{V}\left(\mathrm{H}^{+}\right)$-ATPase B-subunit (white bars) in gill homogenates. All ATPase expressions have been normalized to that of ribosomal protein L10 mRNA in the same samples and are calibrated against the value for $\mathrm{V}\left(\mathrm{H}^{+}\right)$-ATPase expression in the control group $\left(0 \mathrm{mM} \mathrm{L}^{-1} \mathrm{TAN}\right)$. Data are the mean $\pm \operatorname{SEM}(N=5)$ and were analyzed using a one-way ANOVA followed by the Student-Newman-Keuls procedure to locate significantly different means. ${ }^{*} P<0.001$ compared to $\mathrm{V}\left(\mathrm{H}^{+}\right)$-ATPase expression in control shrimps $\left(0 \mathrm{mmol} \mathrm{L}^{-1} \mathrm{TAN}\right)$ and $0.9 \mathrm{mmol} \mathrm{L}^{-1} \mathrm{TAN}$

mRNA expression increased $\approx 2.5$-fold in shrimps exposed to $2.0 \mathrm{mmol} \mathrm{L}^{-1}$ TAN $(P<0.001)$ compared to those at $0.9 \mathrm{mmol} \mathrm{L}^{-1}$ TAN in which expression is similar to control shrimps $(P=0.581)$. Relative rates of $\alpha$-subunit: B-subunit transcription decline from $\approx 4$-fold in the control to 1.5 -fold in $2.0 \mathrm{mmol} \mathrm{L}^{-1} \mathrm{TAN}$, owing to the increase in $\mathrm{V}\left(\mathrm{H}^{+}\right)$-ATPase mRNA transcription.

\subsection{Total hemocyte count}

Total hemocyte count $(\mathrm{THC})$ in shrimps at time $=0$ (before TAN exposure) was $8.7 \times 10^{6}$ hemocytes $\mathrm{mL}^{-1}$ (Fig. 5). THC in shrimps exposed for $72 \mathrm{~h}$ to $0.9 \mathrm{mmol} \mathrm{L}^{-1}$ TAN $\left(8.4 \times 10^{6}\right.$ hemocytes $\left.\mathrm{mL}^{-1}\right)$ was similar $(P=0.632)$ to controls $\left(0 \mathrm{mmol} \mathrm{L}^{-1}\right.$ TAN, $8.8 \times 10^{6}$ hemocytes $\mathrm{mL}^{-1}$ ). However, exposure to $2.0 \mathrm{mmol} \mathrm{L}^{-1}$ TAN resulted in a $30 \%$ decrease in THC $\left(5.3 \times 10^{6}\right.$ hemocytes $\mathrm{mL}^{-1}$; $P<0.05)$ compared to control shrimps.

\subsection{Gill oxidative enzyme activities}

After 72-h exposure to increasing TAN concentrations, superoxide dismutase activity increased significantly $(P=0.006)$ from $\approx 2000 \mathrm{U} \mathrm{mg}^{-1}$ (control shrimps) to $\approx 3500 \mathrm{U} \mathrm{mg}^{-1}$ at $2.0 \mathrm{mmol} \mathrm{L}^{-1}$ TAN (Fig. 6A). Glutathione reductase activity (Fig. 6B) was 1.5fold greater in shrimps exposed to $2.0 \mathrm{mmol} \mathrm{L}^{-1} \mathrm{TAN}\left(\approx 6 \mathrm{U} \mathrm{mg}^{-1}\right.$; $P=0.015)$ compared to control shrimps $\left(\approx 4 \mathrm{U} \mathrm{mg}^{-1}\right)$ while glucose6-phosphate dehydrogenase activity (Fig. 6C) increased 1.5-fold $\left(\approx 2.2 \mathrm{U} \mathrm{mg}^{-1} ; P=0.018\right)$ in shrimps exposed to $2.0 \mathrm{mmol} \mathrm{L}^{-1} \mathrm{TAN}$ compared to control shrimps $\left(\approx 1.5 \mathrm{U} \mathrm{mg}^{-1}\right)$. TAN exposure had no effect $(P=0.534)$ on gill glutathione S-transferase activity (Fig. 6D).

\section{Discussion}

\subsection{Gill $\left(\mathrm{Na}^{+}, \mathrm{K}^{+}\right)$- and $V\left(\mathrm{H}^{+}\right)$-ATPase activities and $m R N A$ expression}

The 2-fold-increase $\left(V_{\mathrm{M}}=316.9 \pm 15.8 \mathrm{nmol} \mathrm{P}_{\mathrm{i}} \mathrm{min}^{-1} \mathrm{mg}^{-1}\right)$ in gill $\left(\mathrm{Na}^{+}, \mathrm{K}^{+}\right)$-ATPase activity seen in $M$. amazonicum when exposed

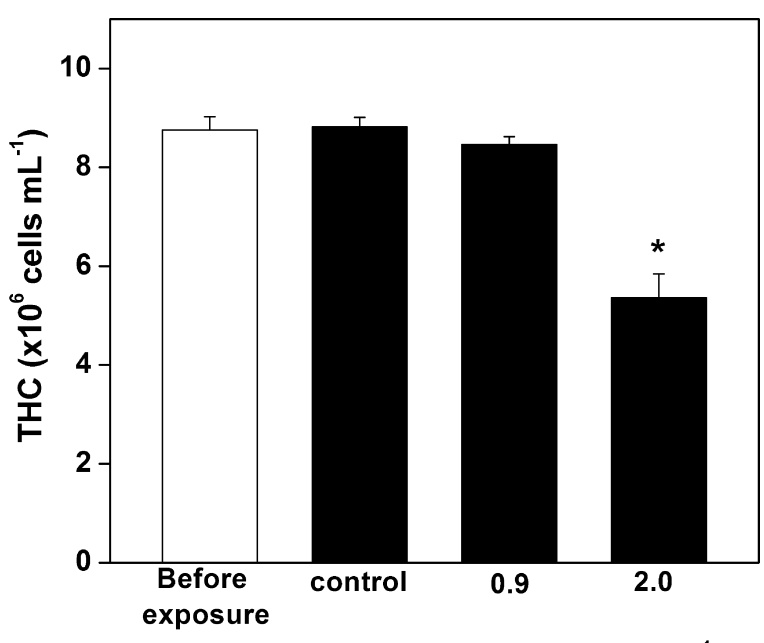

Total ammonia nitrogen $\left(\mathrm{mmol} \mathrm{L}^{-1}\right)$

Fig. 5. Effect of exposure to different total ammonia-N (TAN) concentrations for $72 \mathrm{~h}$ in vivo on total hemocyte count (THC) in the hemolymph of M. amazonicum. Total hemolymph hemocyte counts at time $=0$ ( 4 days before TAN exposure, white bar), and after 72-h exposure to ammonia (black bars). Data are the mean \pm SEM $(N=5) .{ }^{*} P<0.05$ compared to THC in control shrimps exposed to $0 \mathrm{mmol} \mathrm{L}^{-1}$ TAN (ANOVA, SNK).

to elevated TAN likely resulted from the activation of a physiological mechanism to reduce excess ammonia. The minor changes in enzyme affinity for ATP $\left(K_{0.5}=0.08 \pm 0.002 \mathrm{mmol} \mathrm{L}^{-1}\right)$ compared to controls $\left(K_{0.5}=0.07 \pm 0.002 \mathrm{mmol} \mathrm{L}^{-1}\right)$ suggests that even at elevated TAN concentrations, a single enzyme species is responsible for ATP hydrolysis rather than isoenzymes. Interestingly, fresh-caught animals show a maximum $\left(\mathrm{Na}^{+}, \mathrm{K}^{+}\right)$-ATPase activity of $169.9 \pm 0.7 \mathrm{nmol} \mathrm{P}_{\mathrm{i}} \mathrm{min}^{-1} \mathrm{mg}^{-1}$ and $K_{0.5}=1.0 \pm 0.2 \mathrm{mmol} \mathrm{L}^{-1}$ (Leone et al., 2014). Exposure to elevated TAN resulted in a 2fold more active enzyme showing a 12-fold increase ATP affinity. Ammonia exposure of Penaeus chinensis, Macrobrachium nipponense and Portunus pelagicus also increases gill $\left(\mathrm{Na}^{+}, \mathrm{K}^{+}\right)$-ATPase activity (Chen and Nan, 1992; Wang et al., 2003; Romano and Zeng, 2010). Despite the 2 -fold increase in $\left(\mathrm{Na}^{+}, \mathrm{K}^{+}\right)$-ATPase specific activity, $\alpha$-subunit mRNA expression remained unchanged. This suggests that ammonia exposure caused an increase in the maximum rate of $\left(\mathrm{Na}^{+}, \mathrm{K}^{+}\right)$-ATPase activity and an increase in enzyme affinity for ATP. In contrast, gill $\left(\mathrm{Na}^{+}, \mathrm{K}^{+}\right)$-ATPase mRNA expression is down-regulated in Metacarcinus magister after 14-days ammonia exposure (Martin et al., 2011). Given that $\left(\mathrm{Na}^{+}, \mathrm{K}^{+}\right)$-ATPase activity can be stimulated by protein kinases $\mathrm{A}$ and $\mathrm{C}$ or by interaction with the regulatory $\gamma$-subunit (Lucu and Flik, 1999; Therien and Blostein, 2000; Silva et al., 2012), the involvement of these regulators in the response to ammonia exposure cannot be excluded. We have already shown increased $\left(\mathrm{Na}^{+}, \mathrm{K}^{+}\right)$-ATPase activity in response to elevated ammonia in vivo in other decapod crustaceans including Macrobrachium olfersi (34\%; Furriel et al., 2004), M. amazonicum (50\%; Leone et al., 2014), Macrobrachium rosenbergii (22\%; França et al., 2013), Callinectes ornatus (50\%; Garçon et al., 2007), Callinectes danae (90\%; Masui et al., 2002) and Clibanarius vitattus (50\%; Gonçalves et al., 2006). These findings corroborate our previous data showing additional, $\mathrm{Mg}^{2+}$-inhibitable, gill $\left(\mathrm{Na}^{+}, \mathrm{K}^{+}\right)$-ATPase activity in $\mathrm{C}$. danae where $\mathrm{NH}_{4}{ }^{+}$extrusion is underpinned by a second $\mathrm{NH}_{4}{ }^{+}$-binding site that appears when the pump is fully saturated with $\mathrm{K}^{+}$(Masui et al., 2002, 2005).

Ambient ammonia in the aquatic environment is usually low owing to bacterial nitrification of ammonia to nitrate and nitrite (Weihrauch et al., 1999). Indeed, ambient $\mathrm{NH}_{4}{ }^{+}$rarely exceeds $5 \mu \mathrm{M}$ in unpolluted, oxygenated seawater (Koroleff, 1983) while 


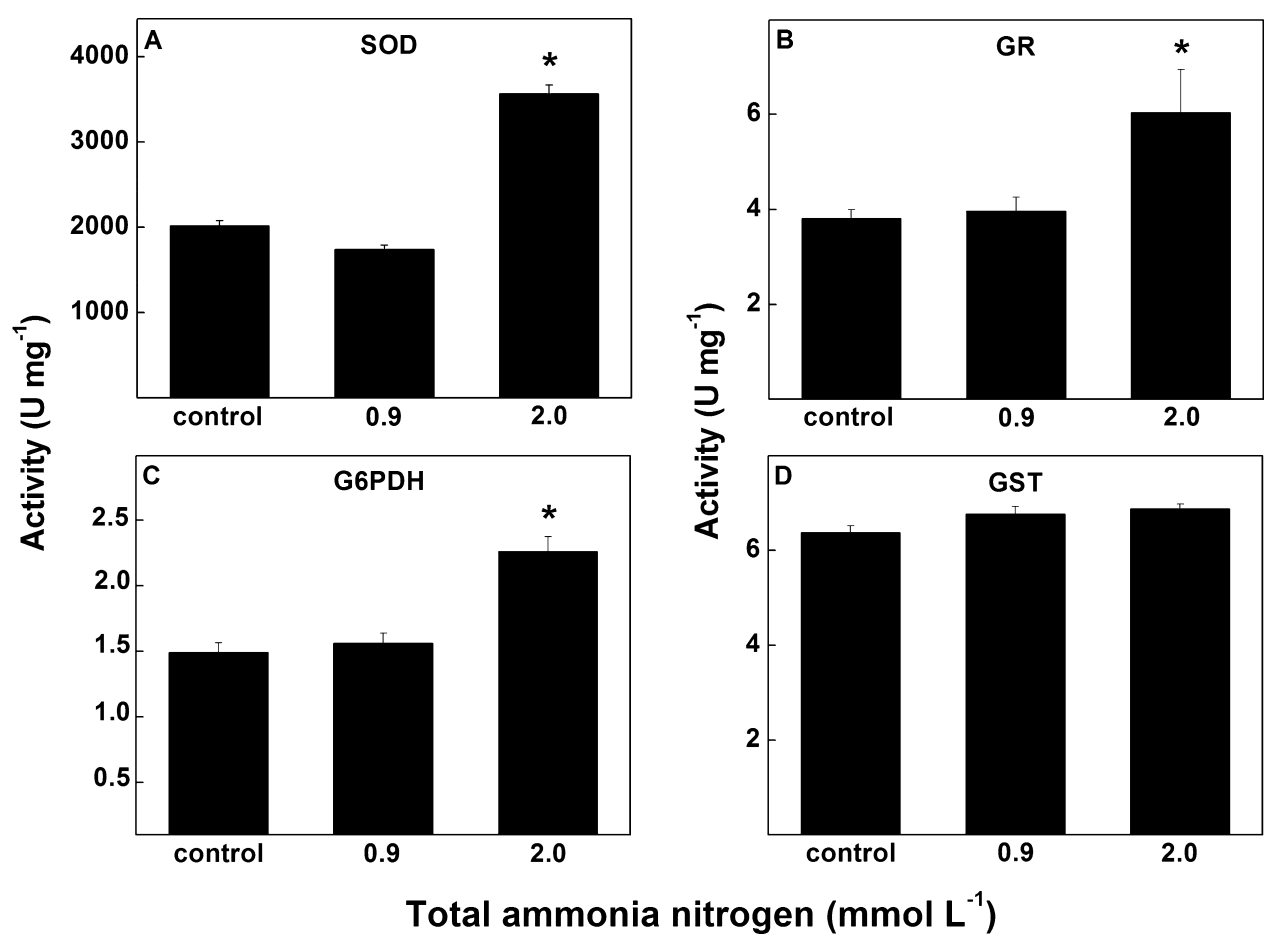

Fig. 6. Effect of exposure in vivo for $72 \mathrm{~h}$ to different total ammonia-N (TAN) concentrations on activity of gill antioxidant enzymes in M. amazonicum.

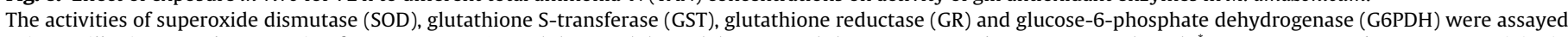

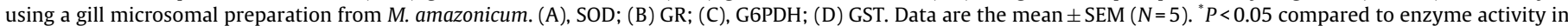
control $\left(0 \mathrm{mmol} \mathrm{L}^{-1}\right)$ and shrimps exposed to $0.9 \mathrm{mmol} \mathrm{L}^{-1}$ ammonia (ANOVA, SNK).

hemolymph concentrations of approximately $100 \mu \mathrm{M}$ are known from various brachyuran species adapted to different salinities (Weihrauch et al., 1999). However, when submitted to acute or chronic ammonia stress, hemolymph ammonia concentrations may increase up to $1.5 \mathrm{mM}$ depending on salinity, ammonia concentration and exposure duration (Romano and Zeng, 2013). Ammonia can be removed from the hemolymph by passive diffusion (Weihrauch et al., 2004a). However, when the ambient ammonia concentration exceeds that of hemolymph, it is excreted against a concentration gradient, maintaining cell function and body fluid ammonia levels within a tolerable range (Weihrauch et al., 2004a). Working models accounting for the effective detoxification or excretion of ammonia, including the active excretion of $\mathrm{NH}_{4}{ }^{+}$driven by the gill $\left(\mathrm{Na}^{+}, \mathrm{K}^{+}\right)$- and $\mathrm{V}\left(\mathrm{H}^{+}\right)$-ATPases, have been developed (Weihrauch et al., 2004a, 2002).

Gill $\mathrm{V}\left(\mathrm{H}^{+}\right)$-ATPase activity increased $\approx 1.5$-fold in $M$. amazonicum after $72 \mathrm{~h}$ exposure to high TAN levels. This alteration in enzyme activity likely results from increased mRNA translation since $\mathrm{V}\left(\mathrm{H}^{+}\right)$-ATPase B subunit mRNA expression increased $\approx 2.5$ fold, suggesting the direct involvement of the $\mathrm{V}\left(\mathrm{H}^{+}\right)$-ATPase in ammonia excretion. This finding corroborates the up-regulation of the $\mathrm{V}\left(\mathrm{H}^{+}\right)$-ATPase B subunit seen in the marine crab $M$. magister after short-term ammonia exposure (Martin et al., 2011). As a consequence of increased $\mathrm{V}\left(\mathrm{H}^{+}\right)$-ATPase expression, $\mathrm{NH}_{3}$ protonation to $\mathrm{NH}_{4}{ }^{+}$is favored, apparently underpinning increased $\mathrm{NH}_{4}{ }^{+}$excretion driven by the $\mathrm{V}\left(\mathrm{H}^{+}\right)$-ATPase. In contrast, mRNA expression of $\left(\mathrm{Na}^{+}, \mathrm{K}^{+}\right)$- and $\mathrm{V}\left(\mathrm{H}^{+}\right)$-ATPases and other transporters involved in gill ammonia excretion are down-regulated after long term exposure to ammonia. This effect is interpreted as a failure of the gill tissue to excrete ammonia (Martin et al., 2011). While gill $\mathrm{V}\left(\mathrm{H}^{+}\right)$-ATPase kinetics have been characterized in several crustaceans (Faleiros et al., 2010; Firmino et al., 2011; Weihrauch et al., 2004b; Onken and Putzenlechner, 1995; Morris, 2001; Lucena et al., 2015), studies relating $\mathrm{V}\left(\mathrm{H}^{+}\right)$-ATPase activity and ammonia exposure are few
(Weihrauch et al., 2002, 2004b; Martin et al., 2011; this study) owing to the prevailing focus on gill osmoregulatory mechanisms. Correlation between ammonia exposure and $\mathrm{V}\left(\mathrm{H}^{+}\right)$-ATPase mRNA expression is still controversial. In the crab Neohelice granulata, $\mathrm{V}\left(\mathrm{H}^{+}\right)$-ATPase mRNA expression is considered a consequence of $\mathrm{V}\left(\mathrm{H}^{+}\right)$-ATPase participation in ammonium excretion by the gills and not a response to altered salinity (Weihrauch et al., 2002, 2004a). Increased $\mathrm{V}\left(\mathrm{H}^{+}\right)$-ATPase activity might generate a favorable $\mathrm{pH}$ gradient across the apical membrane, promoting ammonia excretion by an ammonia trapping mechanism where ammonia transport is mediated via a Rhesus-like transporter (Weihrauch et al., 2009).

\subsection{Immunolocalization of gill $\left(\mathrm{Na}^{+}, \mathrm{K}^{+}\right)$-ATPase and $V\left(H^{+}\right)$-ATPase}

The $\left(\mathrm{Na}^{+}, \mathrm{K}^{+}\right)$-ATPase is located predominantly within the gill intralamellar septal cells in $M$. olfersi, $M$. rosenbergii and M. amazonicum (McNamara and Torres, 1999; França et al., 2013; Leone et al., 2014). Our findings show that exposure to high TAN does not affect enzyme distribution in the gill lamellae of $M$. amazonicum. The $\mathrm{V}\left(\mathrm{H}^{+}\right)$-ATPase is located predominantly in the apical flanges of the gill pillar cells at all TAN concentrations used here in adult M. amazonicum, and in the pillar cells in early and late juveniles (Boudour-Boucheker et al., 2013). However, in shrimps exposed to $2.0 \mathrm{mmol} \mathrm{L}^{-1} \mathrm{TAN}$, the $\mathrm{V}\left(\mathrm{H}^{+}\right)$-ATPase also was encountered in the pillar cell bodies, suggesting that increased ammonium concentrations may redirect part of the newly synthesized enzyme to the cytoplasm, optimizing the vesicular conversion of $\mathrm{NH}_{3}$ to $\mathrm{NH}_{4}{ }^{+}$. In weakly osmoregulating marine crabs like Scylla paramamosain, Macrophtalmus abbreviatus, Macrophtalmus banzai (Tsai and Lin, 2007) and Carcinus maenas (Weihrauch et al., 2001) the gill ionocytes also exhibit a cytosolic $\mathrm{V}\left(\mathrm{H}^{+}\right)$-ATPase distribution. 


\subsection{Total hemocyte count}

The significant decrease in hemolymph hemocyte count of $\approx 30 \%$ after 72 -h ammonia exposure to $2.0 \mathrm{mmol} \mathrm{L}^{-1}$ TAN confirms findings for various crustaceans exposed to high ammonia concentrations (Jiang et al., 2004; Hong et al., 2007; Verghese et al., 2007; Rodríguez-Ramos et al., 2008; Yue et al., 2010). However, our data contrast with those for juvenile $P$. pelagicus in which hemocyte count increases after ammonia exposure (Romano and Zeng, 2010), and for Litopenaeus vannamei (Liu and Chen, 2004), in which hemocyte counts remain unchanged. Shrimp resistance to toxic compounds and/or pathogens is strongly influenced by immune status. The circulating hemocyte is the main defense cell of decapod crustaceans, and plays an important role in regulating exoskeleton hardening, wound repair, carbohydrate metabolism, transport and storage of proteins and amino acids, hemolymph coagulation and confinement of pathogens by clot formation, phagocytosis, and encapsulation (Ratcliffe et al., 1985; Romano and Zeng, 2013). Although total hemocyte count decreases in crustaceans exposed to stress conditions, circulating hemocytes are also affected by extrinsic factors such as temperature, oxygen levels and $\mathrm{pH}$ (Le Moullac and Haffner, 2000; Cheng and Chen, 2002). Besides changes in the gill structure and physiology (Rebelo et al., 2000; Romano and Zeng, 2007), exposure to high ammonia titers can induce alterations in cellular and humoral components of the crustacean immune system (Le Moullac and Haffner, 2000; Liu and Chen, 2004), the release of free oxygen radicals (Le Moullac and Haffner, 2000), hemocyte apoptosis and activation of antioxidant enzymes (Zhang et al., 2015). However, while alterations in hemocyte count in crustaceans exposed to elevated ammonia titers are highly speciesspecific, the mechanism leading to a decreased hemocyte count is not clear as yet (Cheng et al., 2003; Jiang et al., 2004; Liu and Chen, 2004; Hong et al., 2007; Verghese et al., 2007; Rodríguez-Ramos et al., 2008).

\subsection{Gill oxidative enzyme activities}

The increase in gill SOD (1.75-fold), GR (1.5-fold) and G6PDH (1.5-fold) activities, but not in GST activity in M. amazonicum exposed to $2.0 \mathrm{mmol} \mathrm{L}^{-1}$ TAN suggests generation of ROS, as seen in other crustacean species. Exposure of $L$. vannamei to ammonia enhances the generation of ROS, stimulating SOD gene expression and leading to increased enzymatic activity (Liu et al., 2004; Lin et al., 2012). Superoxide dismutase activity in Eriocheir sinensis hemolymph is increased by low ambient ammonia during short term exposure and decreased at higher ammonia concentrations (Hong et al., 2007).

Antioxidant enzymes play an important role in shrimp oxidative defense by scavenging ROS and the superoxide anion (Yu et al., 1994; Lushchak, 2011). SOD activity is often considered to be an indicator of cell oxidant/antioxidant balance in protecting against cellular damage by free radicals (Hong et al., 2007). Most oxidative stress studies of ammonia exposure have been conducted in fish (Ching et al., 2009; Yang et al., 2010; Hegazi et al., 2010; Sinha et al., 2014; Sun et al., 2014) with few studies investigating the influence of ammonia rich environments on the activity of enzymes associated with oxidative stress mechanism in crustaceans (Hong et al., 2007; Zhang et al., 2015; this study). However, the mechanisms by which ammonia induces oxidative stress in aquatic organisms are not well understood in either fish or crustaceans. Environmental ammonia can induce alterations in metabolism and immunity in shrimps, resulting in physiological disturbances like ionic imbalance, slower growth, molting failure, neural disorders, respiratory metabolism impairment, and increased mortality (Alcaraz et al., 1997). Environmental ammonia can also increase levels of lipid peroxidation and SOD activity in fish (Sun et al., 2014), and a given ammonia concentration can also induce differential oxidative stress and different activity profiles in fish (Sinha et al., 2014). Excess ammonia may induce the conversion of xanthine dehydrogenase to xanthine oxidase, increasing ROS production in tilapia (Hegazi et al., 2010). Aquatic organisms may have developed species-specific responses to oxidative stress resulting from changes in TAN concentrations in their environment.

\section{Conclusions}

Under increasing total ammonia-N concentrations, both gill $\left(\mathrm{Na}^{+}, \mathrm{K}^{+}\right)$- and $\mathrm{V}\left(\mathrm{H}^{+}\right)$-ATPase activities are stimulated in vivo. However, while $\left(\mathrm{Na}^{+}, \mathrm{K}^{+}\right)$-ATPase $\alpha$-subunit mRNA expression is unaffected, $\mathrm{V}\left(\mathrm{H}^{+}\right)$-ATPase B-subunit mRNA expression increased $\approx 2.5$-fold in shrimps exposed to $2.0 \mathrm{mmol} \mathrm{L}^{-1}$ TAN. These changes are accompanied by increased activity of many oxidative enzymes with a considerable decrease in hemolymph hemocyte counts. Such findings suggest that the stress responses of $M$. amazonicum to elevated ammonia-N are not limited to a simple increase in $\left(\mathrm{Na}^{+}, \mathrm{K}^{+}\right)$and $\mathrm{V}\left(\mathrm{H}^{+}\right)$-ATPase activity, but involve changes in oxidative stress enzyme activities, immune system effects and alterations in gene expression.

\section{Acknowledgments}

This investigation was supported by research grants from the Conselho Nacional de Desenvolvimento Científico e Tecnológico (CNPq 560501/2101-2), Fundação de Amparo à Pesquisa do Estado de São Paulo (FAPESP, 2010/17534-0; 2011/022537-0; 2013/22605-1) and Fundação de Amparo à Pesquisa do Estado do Amazonas (INCT/CNPq/FAPEAM 573976/2008-2). MRP received a post-doctoral scholarship from CNPq (560501/2010-2), and MNL (2013/24252-9) and ROF (2011/15776-9) from FAPESP. FAL (302776/2011-7), JCM (300564/2013-9) and EAA (307603/2014-8) received research scholarships from CNPq. We thank Nilton R. Alves for technical assistance. We also thank the anonymous reviewers for providing constructive comments. This laboratory (FAL) is integrated with the Amazon Shrimp Network (Rede de Camarão da Amazônia) and with ADAPTA (Centro de Estudos de Adaptações da Biota Aquática da Amazônia). FAL is a Senior Professor at the Departamento de Química, FFCLRP/USP.

\section{References}

Albert, A., 1973. Selective Toxicity, 5 ed. Chapman and Hall, London, England, 597p. Alcaraz, G., Chiappa-Carrara, X., Vanegas, C., 1997. Temperature tolerance of Penaeus setiferus postlarvae exposed to ammonia and nitrite. Aquat. Toxicol. 39, 345-353.

Almeida, E.A., Bainy, A.C.D., Loureiro, A.P.M., Martinez, G.R., Miyamoto, S., Onuki, J., Barbosa, L.F., Garcia, C.C.M., Prado, F.M., Ronsein, G.E., Sigolo, C.A., Brochini, C.B., Martins, A.M.G., Medeiros, M.H.G., Di Mascio, P., 2007. Oxidative stress in Perna perna and other bivalves as indicators of environmental stress in the Brazilian marine environment: antioxidants, lipid peroxidation and DNA damage. Comp. Biochem. Physiol. A 146, 588-600.

Araujo, M.C., Valenti, W.C., 2007. Feeding habit of the Amazon river prawn Macrobrachium amazonicum larvae. Aquaculture 265, 187-193.

Armstrong, D.A., Chippendale, D., Knight, A.W., Colt, J.E., 1978. Interaction of ionized and un-ionized ammonia on short-term survival and growth of prawn larvae, Macrobrachium rosenbergii. Biol. Bull. 154, 15-31.

Augusto, A., Greene, L.J., Laure, H.J., McNamara, J.C., 2007. The ontogeny of isosmotic intracellular regulation in the diadromous, freshwater palaemonid shrimps, Macrobrachium amazonicum and M. olfersi (Decapoda). J. Crustacean Biol. 27, 626-634.

Boudour-Boucheker, N., Boulo, V., Lorin-Nebel, C., Elguero, C., Grousset, E., Anger K., Charmantier-Daures, M., Charmantier, G., 2013. Adaptation to freshwater in the palaemonid shrimp Macrobrachium amazonicum: comparative ontogeny of osmoregulatory organs. Cell Tissue Res. 353, 87-98.

Bradford, M.M., 1976. A rapid and sensitive method for the quantitation of microgram quantities of protein utilizing the principle of protein-dye binding. Anal. Biochem. 72, 248-254. 
Camargo, J.A., Alonso, A., 2006. Ecological and toxicological effects of inorganic nitrogen pollution in aquatic ecosystems: a global assessment. Environ. Int. 32, 831-849.

Carlberg, I., Mannervik, B., 1985. Glutathione reductase. Methods Enzymol. 113, 484-490.

Charmantier, G., Anger, K., 2011. Ontogeny of osmoregulatory patterns in the South American shrimp Macrobrachium amazonicum: loss of hypo-regulation in a land-locked population indicates phylogenetic separation from estuarine ancestors. J. Exp. Mar. Biol. Ecol. 396, 89-98.

Chen, J.C., Nan, N.H., 1992. Effect of ambient ammonia on ammonia-N excretion and ATPase activity of Penaeus chinensis. Aquat. Toxicol. 23, 1-10.

Chen, J.-C., Lin, C.-Y., 1992. Oxygen consumption and ammonia-N excretion of Penaeus chinensis juveniles exposed to ambient ammonia at different salinity levels. Comp. Biochem. Physiol. C 102, 287-291.

Cheng, W., Chen, J.C., 2002. The virulence of Enterococcus to freshwater prawn Macrobrachium rosenbergii and its immune resistance under ammonia stress. Fish Shelliish Immunol. 12, 97-109.

Cheng, W., Chen, S.-M., Wang, F.-I., Hsu, P.-I., Liu, C.-H., Chen, J.-C., 2003. Effects of temperature, $\mathrm{pH}$, salinity and ammonia on the phagocytic activity and clearance efficiency of giant freshwater prawn Macrobrachium rosenbergii to Lactococcus garvieae. Aquacult. Res. 219, 111-121.

Ching, B., Chew, S.F., Wong, W.P., Ip, Y.K., 2009. Environmental ammonia exposure induces oxidative stress in gills and brain of Boleophthalmus boddarti (mudskipper). Aquat. Toxicol. 95, 203-212.

Chourasia, M., Sastry, G.N., 2012. The nucleotide, inhibitor, and cation binding sites of P-type II ATPases. Chem. Biol. Drug Des. 79, 617-627.

Ellis, R.P., Parry, H., Spicer, J.I., Hutchinson, T.H., Pipe, R.K., Widdicombe, S., 2011. Immunological function in marine invertebrates: responses to environmental perturbation. Fish Shellfish Immunol. 30, 1209-1222.

Faleiros, R.O., Goldman, M.H., Furriel, R.P., McNamara, J.C., 2010. Differential adjustment in gill $\mathrm{Na}^{+} / \mathrm{K}^{+}$- and V-ATPase activities and transporter mRNA expression during osmoregulatory acclimation in the cinnamon shrimp Macrobrachium amazonicum (Decapoda, Palaemonidae). J. Exp. Biol. 213, 3894-3905

Firmino, K.C.S., Faleiros, R.O., Masui, D.C., McNamara, J.C., Furriel, R.P.M., 2011 Short-and long-term, salinity-induced modulation of V-ATPase activity in the posterior gills of the true freshwater crab, Dilocarcinus pagei (Brachyura, Trichodactylidae). Comp. Biochem. Physiol. B 160, 24-31.

França, J.L., Pinto, M.R., Lucena, M.N., Garcon, D.P., Valenti, W.C., McNamara, J.C., Leone, F.A., 2013. Subcellular localization and kinetic characterization of a gill $\left(\mathrm{Na}^{+}, \mathrm{K}^{+}\right)$-ATPase from the giant freshwater prawn Macrobrachium rosenbergii. J. Membr. Biol. 246, 529-543.

Furriel, R.P., Masui, D.C., McNamara, J.C., Leone, F.A., 2004. Modulation of gill $\mathrm{Na}^{+}, \mathrm{K}^{+}$-ATPase activity by ammonium ions: putative coupling of nitrogen excretion and ion uptake in the fresh water shrimp Macrobrachium olfersii. J. Exp. Zool. 301, 63-74.

Garçon, D.P., Masui, D.C., Mantelatto, F.L.M., McNamara, J.C., Furriel, R.P.M., Leone, F.A., 2009. Hemolymph ionic regulation and adjustments in gill $\left(\mathrm{Na}^{+}, \mathrm{K}^{+}\right)$-ATPase activity during salinity acclimation in the swimming crab Callinectes ornatus (Decapoda, Brachyura). Comp. Biochem. Physiol. A 154 44-55.

Garçon, D.P., Masui, D.C., Mantelatto, F.L.M., McNamara, J.C., Furriel, R.P.M., Leone, F.A. 2007. $\mathrm{K}^{+}$and $\mathrm{NH}_{4}{ }^{+}$modulate gill $\left(\mathrm{Na}^{+}, \mathrm{K}^{+}\right)$-ATPase activity in the blue crab, Callinectes ornatus: fine tuning of ammonia excretion. Comp. Biochem. Physiol. A 147, 145-155.

Glock, G.E., Mc, L.P., 1953. Further studies on the properties and assay of glucose 6-phosphate dehydrogenase and 6-phosphogluconate dehydrogenase of rat liver. Biochem. J. 55, 400-408.

Gonçalves, R.R., Masui, D.C., McNamara, J.C., Mantellato, F.L.M., Garçon, D.P., Furriel, R.P.M., Leone, F.A., 2006. A kinetic study of the gill $\left(\mathrm{Na}^{+}, \mathrm{K}^{+}\right)$-ATPase, and its role in ammonia excretion in the intertidal hermit crab, Clibanarius vittatus. Comp. Biochem. Physiol. A 145, 346-356.

Hayd, L.A., Anger, K., 2013. Reproductive and morphometric traits of Macrobrachium amazonicum (Decapoda: Palaemonidae) from the Pantanal, Brazil, suggests initial speciation. Rev. Biol. Trop. 61, 39-57.

Hegazi, M.M., Attia, Z.I., Ashour, O.A., 2010. Oxidative stress and antioxidant enzymes in liver and white muscle of Nile tilapia juveniles in chronic ammonia exposure. Aquat. Toxicol. 99, 118-125.

Henry, R.P., Lucu, C., Onken, H., Weihrauch, D., 2012. Multiple functions of the crustacean gill: osmotic/ionic regulation, acid-base balance, ammonia excretion, and bioaccumulation of toxic metals. Front. Physiol. 3 (431)

Holthuis, L.B., 1952. A general revision of the Palaemonidae (Crustacea Decapoda Natantia) of the Americas. II. The subfamily Palaemoninae. Allan Hancock Foundations Publications, Occasional Paper 12, 396p.

Hong, M., Chen, L., Sun, X., Gu, S., Zhang, L., Chen, Y., 2007. Metabolic and immune responses in Chinese mitten-handed crab (Eriocheir sinensis) juveniles exposed to elevated ambient ammonia. Comp. Biochem. Physiol. C 145, 363-369.

Jiang, G., Yu, R., Zhou, M., 2004. Modulatory effects of ammonia-N on the immune system of Penaeus japonicus to virulence of white spot syndrome virus. Aquacult. Res. 241, 61-75.

Johansson, M.W., Keyser, P., Sritunyalucksana, K., Söderhäll, K., 2000. Crustacean haemocytes and haematopoiesis. Aquaculture 191, 45-52.

Keen, J.H., Habig, W.H., Jakoby, W.B., 1976. Mechanism for the several activities of the glutathione S-transferases. J. Biol. Chem. 251, 6183-6188.
Kopecka-Pilarczyk, J., Correia, A.D., 2009. Biochemical response in gilthead seabream (Sparus aurata) to in vivo exposure to a mix of selected PAHs. Ecotoxicol. Environ. Saf. 72, 1296-1302.

Kormanik, G.A., Cameron, J.N., 1981. Ammonia excretion in the seawater blue crab (Callinectes sapidus) occurs by diffusion, and not $\mathrm{Na}^{+} / \mathrm{NH}^{+}$exchange. Comp. Biochem. Physiol. B 141, 457-462.

Koroleff, F., 1983. Determination of ammonia. In: Grasshoff, K., Ehrhart, M., Kremling, K. (Eds.), Methods of Seawater Analysis. , 2 ed. Verlag Chemie, Weinheim, pp. 150-157.

Le Moullac, G., Haffner, P., 2000. Environmental factors affecting immune responses in Crustacea. Aquaculture 191, 121-131.

Leone, F.A., Lucena, M.N., Rezende, L.A., Garçon, D.P., Pinto, M.R., Mantelatto, F.L.M. McNamara, J.C., 2015. Kinetic characterization and immunolocalization of $\left(\mathrm{Na}^{+}, \mathrm{K}^{+}\right)$-ATPase activity from gills of the marine seabob shrimp Xiphopenaeus kroyeri (Decapoda, Penaeidae). J. Membr. Biol. 248, 257-272.

Leone, F.A., Baranauskas, J.A., Furriel, R.P., Borin, I.A., 2005. SigrafW: an easy-to-use program for fitting enzyme kinetic data. Biochem. Mol. Biol. Educ. 33, 399-403.

Leone, F.A., Bezerra, T.M., Garcon, D.P., Lucena, M.N., Pinto, M.R., Fontes, C.F. McNamara, J.C., 2014. Modulation by $\mathrm{K}^{+}$plus $\mathrm{NH}_{4}{ }^{+}$of microsomal $\left(\mathrm{Na}^{+}, \mathrm{K}^{+}\right)$-ATPase activity in selected ontogenetic stages of the diadromous rive shrimp Macrobrachium amazonicum (Decapoda, Palaemonidae). PLoS One 9, e89625.

Lin, Y.C., Chen, J.C., 2001. Acute toxicity of ammonia on Litopenaeus vanname Boone juveniles at different salinity levels. J. Exp. Mar. Biol. Ecol. 259, 109-119.

Lin, Y.C., Chen, J.C., Man, S.N.C., Morni, W.Z.W., Suhaili, A.S.N.A., Cheng, S.Y., Hsu, C.H., 2012. Modulation of innate immunity and gene expressions in white shrimp Litopenaeus vannamei following long-term starvation and re-feeding. Results Immunol. 2, 148-156.

Liu, C.H., Chen, J.C., 2004. Effect of ammonia on the immune response of white shrimp Litopenaeus vannamei and its susceptibility to Vibrio alginolyticus. Fish Shellfish Immunol. 16, 321-334

Livak, K.J., Schmittgen, T.D., 2001. Analysis of relative gene expression data using real-time quantitative PCR and the 2- $\Delta \Delta C(T)$. Methods 25, 402-408.

Lucena, M.N., Garçon, D.P., Mantelatto, F.L.M., Pinto, M.R., McNamara, J.C., Leone, F.A., 2012. Hemolymph ion regulation and kinetic characteristics of the gill $\left(\mathrm{Na}^{+}, \mathrm{K}^{+}\right.$)-ATPase in the hermit crab Clibanarius vittatus (Decapoda, Anomura) acclimated to high salinity. Comp. Biochem. Physiol. B 161, 380-391.

Lucena, M.N., Pinto, M.R., Garcon, D.P., McNamara, J.C., Leone, F.A., 2015. A kinetic characterization of the gill $\mathrm{V}\left(\mathrm{H}^{+}\right)$-ATPase in juvenile and adult Macrobrachium amazonicum, a diadromous palaemonid shrimp. Comp. Biochem. Physiol. B $181,15-25$.

Lucu, C., Flik, G., 1999. $\mathrm{Na}^{+}-\mathrm{K}^{+}$-ATPase and $\mathrm{Na}^{+} / \mathrm{Ca}^{2+}$ exchange activities in gills of hyperregulating Carcinus maenas. Am. J. Physiol. 276, R490-499.

Lushchak, V.I., 2011. Environmentally induced oxidative stress in aquatic animals. Aquat. Toxicol. 101, 13-30.

Magalhães, C., 1985. The larval development of palaemonids from amazon region reared in the laboratory. I. Macrobrachium amazonicum (Heller, (Crustacea, Decapoda). Amazoniana 9, 247-274

Marques, H.L.A., Moraes-Valenti, P.M.C., 2012. Current status and prospects of farming the giant river prawn (Macrobrachium rosenbergii (De Man 1879) and the Amazon river prawn Macrobrachium amazonicum (Heller 1862)) in Brazil. Aquacult. Res. 43, 984-992.

Martin, M., Fehsenfeld, S., Sourial, M.M., Weihrauch, D., 2011. Effects of high environmental ammonia on branchial ammonia excretion rates and tissue Rh-protein mRNA expression levels in sea water acclimated Dungeness crab Metacarcinus magister. Comp. Biochem. Physiol. A 160, 267-277.

Masui, D.C., Mantelatto, F.L., McNamara, J.C., Furriel, R.P., Leone, F.A., 2009. $\mathrm{Na}^{+}$ $\mathrm{K}^{+}$-ATPase activity in gill microsomes from the blue crab, Callinectes danae, acclimated to low salinity: novel perspectives on ammonia excretion. Comp. Biochem. Physiol. A 153, 141-148

Masui, D.C., Silva, E.C.C., Mantelatto, F.L.M., McNamara, J.C., Barrabin, H., Scofano H.M., Fontes, C.F.L., Furriel, R.P.M., Leone, F.A., 2008. The crustacean gill $\left(\mathrm{Na}^{+}, \mathrm{K}^{+}\right)$-ATPase: allosteric modulation of high- and low-affinity ATP-binding sites by sodium and potassium. Arch. Biochem. Biophys. 479, 139-144

Masui, D.C., Furriel, R.P., Silva, E.C., Mantelatto, F.L., McNamara, J.C., Barrabin, H., Scofano, H.M., Fontes, C.F., Leone, F.A., 2005. Gill microsomal $\left(\mathrm{Na}^{+}, \mathrm{K}^{+}\right)$-ATPase from the blue crab Callinectes danae: interactions at cationic sites. Int. J. Biochem. Cell Biol. 37, 2521-2535.

Masui, D.C., Furriel, R.P., McNamara, J.C., Mantelatto, F.L., Leone, F.A., 2002. Modulation by ammonium ions of gill microsomal $\left(\mathrm{Na}^{+}, \mathrm{K}^{+}\right)$-ATPase in the swimming crab Callinectes danae: a possible mechanism for regulation of ammonia excretion. Comp. Biochem. Physiol. C 132, 471-482.

McCord, J.M., Fridovich, I., 1969. Superoxide dismutase. An enzymic function for erythrocuprein (hemocuprein). J. Biol. Chem. 244, 6049-6055.

McNamara, J., Moreira, G., Moreira, P., 1983. The effect of salinity on respiratory metabolism, survival and moulting in the first zoea of Macrobrachium amazonicum (Heller) (Crustacea, Palaemonidae). Hydrobiologia 101, 239-242.

McNamara, J.C., Torres, A.H., 1999. Ultracytochemical location of $\mathrm{Na}^{+} / \mathrm{K}^{+}$-ATPase activity and effect of high salinity acclimation in gill and renal epithelia of the freshwater shrimp Macrobrachium olfersii (Crustacea, Decapoda). J. Exp. Zool. 284, 617-628.

Moore, S., Stein, W.H., 1954. A modified ninhydrin reagent for the photometric determination of amino acids and related compounds. J. Biol. Chem. 211 907-913.

Morris, S., 2001. Neuroendocrine regulation of osmoregulation e the evolution of air-breathing in decapods crustaceans. J. Exp. Biol. 204, 979-989. 
Muta, T., Iwanaga, S., 1996. The role of hemolymph coagulation in innate immunity. Curr. Opin. Immunol. 8, 41-47.

O’Donnell, M.J., 1997. Mechanisms of excretion and ion transport in invertebrates Comprehensive Physiology, Supplement 30: Handbook of Physiology, Comparative Physiology, Wiley-Blackwell, Hoboken, USA, 1207-1289.

Onken, H., Putzenlechner, M., 1995. A V-ATPase drives active, electrogenic and $\mathrm{Na}^{+}$-independent $\mathrm{Cl}^{-}$absorption across the gills of Eriocheir sinensis. J. Exp. Biol. 198, 767-774

Peebles, J.B., 1977. A rapid technique for molt staging in live Macrobrachium rosenbergii. Aquaculture 12, 173-180.

Peterson, G.L., Hokin, L.E., 1981. Molecular weight and stoichiometry of the sodium- and potassium- activated adenosine triphosphatase subunits. J. Biol. Chem. 256, 3751-3761.

Pfaffl, M.W., 2001. A new mathematical model for relative quantification in real-time RT-PCR. Nucleic Acids Res. 29, e45.

Poulsen, H., Morth, P., Egebjerg, J., Nissen, P., 2010. Phosphorylation of the $\mathrm{Na}^{+}, \mathrm{K}^{+}$-ATPase and the $\mathrm{H}^{+}, \mathrm{K}^{+}$-ATPase. FEBS Lett. 584, 2589-2595.

Ratcliffe, N.A., Rowley, A.F., Fitzgerald, S.W., Rhodes, C.P., 1985. Invertebrate immunity: basic concepts and recent advances. Int. Rev. Cytol. 97, 183-350.

Read, S.M., Northcote, D.H., 1981. Minimization of variation in the response to different proteins of the Coomassie blue G dye-binding assay for protein. Anal. Biochem. 116, 53-64.

Rebelo, M.F., Rodriguez, E.M., Santos, E.A., Ansaldo, M., 2000. Histopathologica changes in gills of the estuarine crab Chasmagnathus granulata (Crustacea-Decapoda) following acute exposure to ammonia. Comp. Biochem. Physiol. C 125, 157-164.

Rodríguez-Ramos, T., Espinosa, G., Hernández-López, J., Gollas-Galván, T., Marrero J., Borrelle, Y., Alonso, M.E., Ubaldo Bécquer Alonso, M., 2008. Effects of Echerichia coli lipopolysaccharides and dissolved ammonia on immune response in southern white shrimp Litopenaeus schmitti. Aquacult. Res., $118-125$.

Romano, N., Zeng, C., 2007. Ontogenetic changes in tolerance to acute ammonia exposure and associated histological gill alterations during early juvenile development of the blue swimmer crab, Portunus pelagicus. Aquaculture 266, 246-254.

Romano, N., Zeng, C., 2010. Changes to the histological gill structure and haemolymph composition of early blue swimmer crab Portunus pelagicus juveniles during elevated ammonia-N exposure and the post-exposure recovery. Aquacult. Res. 41, 468-480.

Romano, N., Zeng, C., 2013. Toxic effects of ammonia, nitrite, and nitrate to decapoc crustaceans: a review on factors influencing their toxicity, physiological consequences, and coping mechanisms. Rev. Fisheries Sci. 21,1-21.

Santos, L.C., Belli, N.M., Augusto, A., Masui, D.C., Leone, F.A., McNamara, J.C., Furriel R.P., 2007. Gill $\left(\mathrm{Na}^{+}, \mathrm{K}^{+}\right)$-ATPase in diadromous, freshwater palaemonid shrimps: species-specific kinetic characteristics and alpha-subunit expression. Comp. Biochem. Physiol. A 148, 178-188.

Silva, E.C., Masui, D.C., Furriel, R.P., McNamara, J.C., Barrabin, H., Scofano, H.M., Perales, J., Teixeira-Ferreira, A., Leone, F.A., Fontes, C.F., 2012. Identification of a crab gill FXYD2 protein and regulation of crab microsomal Na,K-ATPase activity by mammalian FXYD2 peptide. Biochim. Biophys. Acta 1818, 2588-2597.

Sinha, A.K., AbdElgawad, H., Giblen, T., Zinta, G., De Rop, M., Asard, H., Blust, R., De Boeck, G., 2014. Anti-oxidative defences are modulated differentially in three freshwater teleosts in response to ammonia-induced oxidative stress. PLoS One 9, e95319.

Skou, J., Esmann, M., 1992. The Na,K-ATPase. J. Bioenergy Biomembr. 24, 249-261.
Sun, H., Wang, W., Li, J., Yang, Z., 2014. Growth, oxidative stress responses, and gene transcription of juvenile bighead carp (Hypophthalmichthys nobilis) under chronic-term exposure of ammonia. Environ. Toxicol. Chem./SETAC 33, $1726-1731$.

Therien, A.G., Blostein, R., 2000. Mechanisms of sodium pump regulation. Am. J Physiol. Cell Physiol. 279, C541-566.

Towle, D.W., Holleland, T., 1987. Ammonium ion substitutes for $\mathrm{K}^{+}$in ATP-dependent $\mathrm{Na}^{+}$transport by basolateral membrane vesicles. Am. J. Physiol. 252, R479-489.

Toyoshima, C., Iwasawa, S., Ogawa, H., Hirata, A., Tsueda, J., Inesi, G., 2013. Crystal structures of the calcium pump and sarcolipin in the $\mathrm{Mg}^{2+}$-bound E1 state. Nature 495, 260-264.

Tsai, J.R., Lin, H.C., 2007. V-type $\mathrm{H}^{+}$-ATPase and $\mathrm{Na}^{+}, \mathrm{K}^{+}$-ATPase in the gills of 13 euryhaline crabs during salinity acclimation. J. Exp. Biol. 210, 620-627.

Verghese, B., Radhakrishnan, E.V., Padhi, A., 2007. Effect of environmental parameters on immune response of the Indian spiny lobster, Panulirus homarus (Linnaeus, 1758). Fish Shellfish Immunol. 23, 928-936.

Wang, A.-L., Wang, W.-N., Wang, Y., Shang, L.-X., Liu, Y., Sun, R.-Y., 2003. Effect of dietary vitamin $C$ supplementation on the oxygen consumption, ammonia- $N$ excretion and $\mathrm{Na}^{+} / \mathrm{K}^{+}$ATPase of Macrobrachium nipponense exposed to ambient ammonia. Aquaculture 220, 833-841.

Wang, L.U., Chen, J.C., 2005. The immune response of white shrimp Litopenaeus vannamei and its susceptibility to Vibrio alginolyticus at different salinity levels. Fish Shellfish Immunol. 18, 269-278.

Weihrauch, D., Becker, W., Postel, U., Luck-Kopp, S., Siebers, D., 1999. Potential of active excretion of ammonia in three different haline species of crabs. J. Comp. Physiol. B 169, 25-37

Weihrauch, D., Ziegler, A., Siebers, D., Towle, D.W., 2001. Molecular characterization of V-type $\left(\mathrm{H}^{+}\right)$-ATPase (B-subunit) in gills of euryhaline crabs and its physiological role in osmoregulatory ion uptake. J. Exp. Biol. 204, 25-37.

Weihrauch, D., Ziegler, A., Siebers, D., Towle, D.W., 2002. Active ammonia excretion across the gills of the green shore crab Carcinus maenas: participation of $\mathrm{Na}\left({ }^{+}\right) / \mathrm{K}\left({ }^{+}\right)$-ATPase, $\mathrm{V}$-type $\left.\mathrm{H}^{+}\right)$-ATPase and functional microtubules. J. Exp. Biol. 205, 2765-2775

Weihrauch, D., McNamara, J.C., Towle, D.W., Onken, H., 2004a. Ion-motive ATPases and active, transbranchial $\mathrm{NaCl}$ uptake in the red freshwater crab, Dilocarcinus pagei (Decapoda, Trichodactylidae). J. Exp. Biol. 207, 4623-4631.

Weihrauch, D., Morris, S., Towle, D.W., 2004b. Ammonia excretion in aquatic and terrestrial crabs. J. Exp. Biol. 207, 4491-4504.

Weihrauch, D., Wilkie, M.P., Walsh, P.J., 2009. Ammonia and urea transporters in gills of fish and aquatic crustaceans. J. Exp. Biol. 212, 1716-1730.

Yang, W., Xiang, F., Liang, L., Yang, Z., 2010. Toxicity of ammonia and its effects on oxidative stress mechanisms of juvenile crucian carp (Carassius auratus). J. Freshwater Ecol. 25, 297-302.

Yu, L., Gengaro, P., Burke, T.J., Schrier, R.W., 1994. Reactive oxygen species (ROS) are involved in rat tubular hypoxia-reoxygenation (H/R) injury. Kidney Int. 46, 1747.

Yue, F., Pan, L., Miao, J., Zhang, L., Li, J., 2010. Molecular cloning, characterization and mRNA expression of two antibacterial peptides: crustin and anti-lipopolysaccharide factor in swimming crab Portunus trituberculatus. Comp. Biochem. Physiol. B 156, 77-85.

Zhang, Y., Ye, C., Wang, A., Zhu, X., Chen, C., Xian, J., Sun, Z., 2015. Isolated and combined exposure to ammonia and nitrite in giant freshwater pawn (Macrobrachium rosenbergii): effects on the oxidative stress, antioxidant enzymatic activities and apoptosis in haemocytes. Ecotoxicology, 1-10. 